\title{
How much state ownership do hybrid firms need for better performance?
}

\author{
Bach Nguyen $\cdot$ Hoa Do $\cdot$ Chau Le
}

Accepted: 18 August 2021 / Published online: 28 October 2021

(C) The Author(s) 2021

\begin{abstract}
Hybrid ownership—sharing partial business ownership with the state-is a new form of political connections that entrepreneurs in developing countries may employ to improve their access to key resources. This study investigates hybrid ownership as a strategic decision of entrepreneurs running small businesses in Vietnam-a transition economy. Utilising the resource dependence theory and legitimacy viewpoint, we propose and evidently show that increased state ownership in hybrid firms leads to improved performance. However, increasing state ownership beyond a minority share threshold harms firm performance due to the presence of agency costs. Also, the involvement of the state in firm governance reduces the benefits gained from having state ownership.
\end{abstract}

Plain English Summary Is the more the better? How much state ownership really matters for hybrid

\footnotetext{
B. Nguyen

Aston Business School, Aston University,

Birmingham B47ET, UK

e-mail: nguyenb1@ aston.ac.uk
}

\section{H. Do $(\square)$}

Nottingham Business School, Nottingham Trent

University, Nottingham NG14FQ, UK

e-mail: hoa.do@ntu.ac.uk

C. Le

School of Banking, University of Economics HCMC,

Ho Chi Minh City, Vietnam

e-mail: chaulha@ueh.edu.vn firms to enhance their performance? More state ownership means more access to resources and privileges; but too much state ownership may reduce firm efficiency due to its poor governance. Analysing more than one million observations of small businesses in Vietnam, this study offers three insightful implications. First, for academics, institutional conditions should be considered when investigating political connections, especially in an emerging market context. Second, for practitioners, political connections in the form of hybrid ownership when being held at an adequate level can boost firm performance. However, an exceeding level of state ownership in hybrid firms may become harmful. Third, for policymakers, we suggest that forming hybrid business ownership with the private sector helps firms make use of stateowned resources. This collaboration is a win-win solution as long as the state ownership remains at an adequate level.

Keywords Hybrid firms · Political connections · Firm performance $\cdot$ Vietnam $\cdot$ Weak institutions . $\mathrm{D} 02 \cdot \mathrm{P} 23 \cdot \mathrm{M} 13$

JEL Classifications $\quad$ D02 $\cdot$ P23 $\cdot$ M13

\section{Introduction}

Political connections are relevant for all kinds of institutions but are more accurate in the context of 
emerging markets where their institutional conditions and legal issues are not fully developed, more complex and/or incomplete (Wang, Zhang, Xu, \& Shu, 2018; Wong \& Hooy, 2018; Zhou, 2013). Given these institutional weaknesses in developing countries, key strategic resources such as regulation favours, information, government subsidies and bank loans are largely controlled by the state (Aidis, Estrin, \& Mickiewicz, 2008; Ding et al., 2018; Du et al., 2015). In such an environment, entrepreneurs running small private businesses must build political connections with the government.

Given how topical political connections are, a vibrant research theme emerges in the literature (Sharma et al., 2020; Wang et al., 2018; Wong \& Hooy, 2018; Zhou, 2017). Many authors have focused on the bright side of political connection establishments such as government subsidies, bank loans, direct contracts, tax breaks as well as their effects on firm value and performance (Feng et al., 2015; Johnson \& Mitton, 2003; Li, Meng, Wang, \& Zhou, 2008; Wang et al., 2018). Others find it important and useful to build political connections in order to gain access to the resources needed for their venturing activities (Zhou, 2013; Zhou, 2017). However, some authors have highlighted the dark side of political connections by showing that such connections create no value for firms (Fisman et al., 2012).

Despite progress, several important gaps need to be addressed. First, the impact of political connections on firm value and performance is found to be mixed despite scholarly efforts (Sharma et al., 2020; Wang et al., 2018). Second, the literature examining the benefits of political connections has focused on networking connections at the individual level, such as Guanxi, with local authorities. ${ }^{1}$ This type of connection is informal, thereby being unreliable (Bian, 2017). Less frequently examined is political connections at the organisational level (Song et al., 2015), where entrepreneurs establish an institutionalised relationship with the government through an explicit,

\footnotetext{
${ }^{1}$ Guanxi is a social tie in which relative trust is high and is not dependent on third parties (Burt \& Burzynska, 2017). Guanxi serves as a mechanism by which quasi-familial relations can be created to cultivate trust among non-kin (Guo \& Miller, 2010). This type of social tie is specific to China and other countries in the Southeast Asian region (Bian, 2017; Luo, Huang, \& Wang, 2012).
}

written, legal contract, which allows them to secure access to resources. This gap may limit our understanding of the important consequences of firm-level political ties on new ventures.

Also, political connections have been rarely investigated out of the context of China. We fill in this gap by focusing on Vietnam-an emerging market, which is characterised by its institutional complexity with its mixed economic model that entails both socialist and market economy traits. Vietnam therefore provides a perfect context for exploring the effects of political connections on firm performance because this institutional complexity may influence how affiliated firms establish their political connections with the government. However, we know relatively little about this phenomenon in this context. Taken as a whole, more research is needed not only on scholarly insight into this phenomenon and its consequences, but also on theorising how political connections influence firm performance in a unique context such as Vietnam.

Specifically, in this study we ask: (1) whether state ownership is essential and beneficial for hybrid firms? and (2) if so, how much they actually need to increase their performance? We hypothesise that as state ownership increases, hybrid firms gain more access to resources controlled by the state and become more legitimate in the eyes of stakeholders. These effects enhance firm performance via increased business opportunities and financial leverage. However, this process also implies that entrepreneurs in hybrid firms must trade off their control rights over the governance of the business against improved access to resources and legitimacy. As such, due to the agency costs associated with state ownership, governance efficiency reduces sharply as state ownership increases significantly (Du et al., 2014; O'Toole, Morgenroth, \& Ha, 2016), leading to a reduction in firm performance. This is consistent with the situation of state-owned firms, whose privileges fail to improve their performance because of agency problems.

Empirically, employing a fixed-effect method for panel data of Vietnam's small businesses over the period from 2006 to 2018 with appropriate controls for potential endogeneity and multi-level structure of the dataset, we find that when hybrid firms increase state ownership, they become less sensitive to bureaucratic harassments, leading to improved performance. However, increasing state ownership beyond the 50\% threshold harms firm performance. 
Our contribution is fourfold. First, our study contributes to the literature on strategic entrepreneurship by providing a broadened view on political relationship building by small businesses in developing countries. While the majority of studies have focused on the benefits of political connections, our study focuses on the dark side of political embeddedness. Specifically, we suggest that an appropriate level of state ownership helps boost hybrid firm performance; however, an excessive level of state ownership may be harmful. This study therefore sheds new light on the dark side of political connections that add no value to firms (Fisman et al., 2012). Second, this study is among the first to examine political relationship building from the viewpoint of organisational strategy rather than individual informal networking.

Third, this study contributes to the literature by examining the establishment and evolution of the entrepreneurial sector-private small and young businesses (Du \& Mickiewicz, 2016) in Vietnam. It expands the context of analysis of political affiliated businesses out of the conventional empirical settings of China and focuses on the fast-developing but unexplored context of Vietnam. Given the mixed nature of institutions between socialist ideologies and market-based principles (Awaworyi Churchill, Munyanyi, Smyth, \& Trinh, 2020), the literature has highlighted that small and young firms in Vietnam need to employ unique strategies to "play the institutional game" and gain access to key resources, which are under the control of the state. This study suggests that sharing ownership with the government could be a feasible but unexplored strategy.

Finally, this study has insightful implications for entrepreneurs in Vietnam in specific and developing countries in general. While it is beneficial to share equity ownership with the state in less developed institutional environments, entrepreneurs need to retain control of their business governance. Such a strategy would help small firms gain access to key resources and obtain legitimacy while still remaining efficient and performance-driven.

\section{Institutional background of Vietnam}

Scholars have recently highlighted the vital importance of the context in theorising and understanding its influence on entrepreneurial environments (Welter, 2011; Welter \& Baker, 2020). This is important because there is often a close interaction between entrepreneurs and their business environments over time to construct and enact the places in which they are embedded (Welter \& Baker, 2020). In today's increasingly global business environment, the context/place may become even more important because it is a decisive factor that may enable us to record all sorts of potential complicated differences in contexts such as between different countries that may influence entrepreneurial identities and actions (Welter $\&$ Baker, 2020). Taking the context into account will provide us with more opportunities to advance our theories by choosing different viewpoints to approach a research topic (Welter \& Baker, 2020).

Specifically, we decided to choose Vietnam as a unique and interesting context for this study for several reasons. First, Vietnam is known as its mixture of socialist- and capitalist-orientated economy (Do et al., 2020), thereby being especially unique in comparison with other countries. As a post-communist economy, the Vietnamese government is still the key player of the whole national economy, and thus controls most of the country's key strategic resources, including financial markets and land use rights (Nguyen, Mickiewicz, \& Du, 2018). Second, the institutional arrangements of the country remain biased heavily toward the state sector (Nguyen \& van Dijk, 2012). Entrepreneurs must therefore put significant effort into building political relationships in order for their ventures to survive and grow. Khuong (2015), in a comparison of the economic reforms in Vietnam and China, suggests that Vietnam remains less open to the private sector than China; leading to a situation in which entrepreneurs in Vietnam need to exert more effort than entrepreneurs in China to gain access to key resources.

Third, Vietnam is an emerging economy characterised by the booming of the entrepreneurial sector (young and small private businesses). Such firms are the key driver of Vietnam's phenomenal economic transformation over the last decade (Nguyen et al., 2018). In particular, Tran (2019) offers a discussion of the economic transition process in Vietnam and explains that the liberalisation phase of reforms was only achieved from the year 2000 onwards. This is why the population of private firms is very young, with an average firm age in our sample is 6.2 years. The smallness and youngness of most private firms 
in Vietnam imply that they need to build up political connections, including sharing ownership with the government, to gain access to resources for survival and growth. Taken together, the institutional conditions exert a profound influence on the establishment of Vietnamese firms and their ownership structure. This study therefore contributes to theory by contextualising entrepreneurship scholarship that is often criticised for not having paid enough attention to the theorisation of context (Welter \& Baker, 2020).

\section{Literature and hypotheses}

\subsection{Institutional incompleteness and hybrid entrepreneurship}

In weak institutional environments (e.g., developing economies), key strategic resources such as capital, land, information, technology, and human resources are controlled by the state (Nguyen, 2019). In such a constrained situation, firms often actively engage in purposeful political activities to secure access to these resources and reduce the impacts of institutional uncertainty (Ding et al., 2018; Zhou, 2013). Firms may engage in several forms of political activities. One strategy is to create social connections, which is where entrepreneurs actively strive to build their social capital and create political connections by entertaining and giving gifts to local authorities in their social networks (Bian, 2018; Luo et al., 2012). In the context of China, this strategy has been found to improve firms' access to external financing (shortterm debts) (Du et al., 2015). Along the same lines, entrepreneurs may actively enhance their political status (Faccio, 2010; Goldman, Rocholl, \& So, 2009) or exploit the political status of people in their personal networks, including their father, mother, spouse, adult children, other intimate relatives, and close friends. This strategy also has been found to be positively related to entrepreneurial investment in the context of China (Zhou, 2013).

While the majority of the literature is concerned with political connections at the personal level, only a little research focuses on political connections at the institutional level (Song, Nahm, \& Yang, 2016). The latter strategy-conducted by so-called government-private hybrid firms - takes the form of an explicit, written, legal contract, based upon which entrepreneurial firms build a formal connection with the government. There are three typical connection types. In the "red-hat" type of firm, a private entrepreneur gets permission from a government agency to register her business as a de jure government-owned firm. The firm then pays an annual "management fee" to the government while operating as a normal private business (Chen, 2015; Peng, Lu, Shenkar, \& Wang, 2001). In the "rented" type of firm, a private entrepreneur rents a government-owned firm on a longterm basis following one-to-one bargaining with the government. The entrepreneur has full control over the governance and operation (but not ownership) of the firm, but once again, he/she must share residual income streams with the government (Lipton, Sachs, \& Summers, 1990; Megginson \& Netter, 2001).

Both of these hybrid firms, though de facto private, are legally owned by the government, and they were quite popular in China, Vietnam, and Eastern European countries in 1980s and 1990s (Chen, 2015; Lipton et al., 1990; Walder \& Nguyen, 2008). However, their numbers have reduced significantly over the last decade (Zhou, 2017), leaving room for the emergence of the third type of hybrid form-mixed ownership. ${ }^{2}$

Mixed ownership hybrid firms are those businesses whose shares are owned by both private entrepreneurs and the government (Song et al., 2015). Technically speaking, the shares owned by the government in this type of firm could be any percentage, as long as it is not zero percent (i.e., private firms) or one hundred percent (i.e., state-owned firms). This type of hybrid firm is becoming more and more popular as privatisation increases in post-communist economies (Song, Nahm, \& Zhang, 2017). However, there is hardly any research that systematically examines mixed ownership hybrid firms from the strategic entrepreneurship viewpoint. As such, unlike the strand of research that investigates the economic consequences of privatised large corporations (see Divya Verma \& Abhijit, 2018 for a review), we focus on the strategies employed by entrepreneurs aimed at establishing political affiliation via the route of sharing their (small) businesses' ownership with the government. The literature is as

\footnotetext{
${ }^{2}$ Wang et al. (2018) document that, in the context of China, the termination of political connections results in an approximately $2 \%$ decline in equity value for private firms. As such, private firms are motivated to find a new way of maintaining/ strengthening their (formal) connections with the government.
} 
yet silent about how effective this strategy is at coping with institutional voids. This study fills that gap.

\subsection{Hybrid firms, private firms, and state-owned firms}

In weak institutional environments, both private and state-owned firms have their specific shortcomings and disadvantages. Private firms are typically discriminated against by the legislative systems (Allen et al., 2005; Boudreaux \& Nikolaev, 2019) and the financial markets (Allen et al., 2005; Guariglia \& Liu, 2014), both of which are in place primarily to support state-owned firms (Du et al., 2015). In the context of Vietnam, for example, it is found that private firms have limited access to land and landuse rights, operation permits, bank loans, and financial subsidies in comparison with state-owned firms (Malesky, McCulloch, \& Nhat, 2015; Nguyen, 2019; Nguyen, Le, \& Freeman, 2006). Thus, private firms are restricted from leveraging resources. Meanwhile, state-owned firms, even though their access to key strategic resources is unhindered, may fail to utilise these resources effectively to maximise profits due to agency problems associated with the manager-owner governance system (Liu, Zhang, Fang, \& Chen, 2021), which prevent them from operating an efficient system of corporate governance.

In this regard, the establishment of mixed ownership hybrid firms, in accordance with resource dependence theory (RDT) (Pfeffer \& Salancik, 1978), may be a solution. Specifically, RDT proposes that resources are key to organisational success and that access to and control over resources is a source of power. As such, entrepreneurs are incentivised to increase their acquisition and control over resources through a set of strategies that includes sharing ownership of the business with the government (i.e., the owner of the resources). In this way, hybrid firms, thanks to their partial state ownership, can obtain access to crucial resources controlled by the state (Zhou, 2017). Some empirical evidence has initially supported this argument. For instance, in a series of studies on mixed ownership in publicly listed firms in China, Song and colleagues show that hybrid corporates gain more access to bank loans, credits, and operation permits in industries to which formal barriers restrict entry (Song et al., 2016; Song et al., 2015; Song et al., 2017). Also, Chinese politically affiliated firms are more likely to engage in productive activities to improve earnings (Zhou, 2014) as well as in risktaking behaviours (Ding, Jia, Qu, \& Wu, 2015) than non-affiliated counterparts. Therefore, hybrid ownership - a firm-level strategic approach to political affiliation-is expected to improve firm performance.

In addition to access to resources, mixed ownership may help hybrid firms gain legitimacy in their local business environment. Legitimacy is "a generalised perception or assumption that the actions of an entity are desirable, proper, or appropriate within some socially constructed system of norms, values, beliefs, and definitions" (Suchman, 1995, p. 574). Hence, once a firm has legally obtained a hybrid form, it may utilise the signalling effect to send a positive message about its credentials to stakeholders, strengthening its market position. Also, being a "legitimate business" in an institutional environment that shows favouritism to state-owned enterprise may help hybrid firms to avoid, to some extent, harassments such as corruption and bureaucracy (Kuratko, Fisher, Bloodgood, \& Hornsby, 2017). Some initial empirical evidence has confirmed this line of argument. For example, $\mathrm{Li}$, Chen, Gao, and Xie (2019) find that obtaining government R\&D subsidies has a certification effect, which is used by Chinese entrepreneurial firms as a legitimation strategy to access bank finance. Furthermore, Cheng, Chan, and Leung (2018) suggest that Guanxi-related perks play an essential marketing role in enhancing long-term success. Meanwhile, in Vietnam, evidence shows that the frequency of interaction with public officials is negatively associated with bribe values (Rand \& Tarp, 2012) and positively associated with the duration of bank loans (Pham \& Talavera, 2018).

In short, we propose that hybrid firms may gain more competitive advantages than their private counterparts. These competitive advantages come from (1) access to key strategic resources, and (2) improved legitimacy. Meanwhile, hybrid firms may be more efficient than state-owned firms in utilising resources because they face fewer owner-manager agency problems (Liu et al., 2021). As such, we draw upon the RDT and legitimacy viewpoint to highlight the importance of hybrid firms' capacity to gain access to external resources and establish their legitimacy, leading to improved performance ultimately. We propose the following:

Hypothesis H1: There is an association between firm ownership structure and firm performance. 


\subsection{Hybrid ownership and performance}

While it is argued that hybrid firms perform better than their private and state-owned counterparts, we suspect that, within the group of hybrid firms, there is substantial heterogeneity in performance, depending on the proportion of state ownership. Specifically, we expect that when state ownership is at a minor level, an increase in state ownership will foster firm performance. However, an excessive level of state ownership may be harmful.

In accordance with the general corporate governance principles, a shareholder or a group of shareholders holding more than $50 \%$ of equity shares of a firm can take over the power of governance or appoint a representative to do so, unless otherwise agreed with the minor shareholders (Tricker, 2015). As such, when state ownership in a hybrid firm exceeds $50 \%$, it is the state (aka the government official appointed to represent the state) rather than the entrepreneur who makes the final decisions on firm governance and development strategies. We now turn to discussing two cases: (1) when state ownership is minor, and (2) when state ownership is major.

\subsubsection{When state ownership is less than 50\%}

When the state plays as a minor owner in hybrid firms, by laws, the appointed officials representing the state do not have the right to make the final decision regarding firm operations and strategies. Entrepreneurs who hold the majority of the shares have the right to do so. At this stage, an increase in state ownership (as long as it does not exceed 50\%) will bring about benefits for hybrid firms in terms of both enhanced legitimacy and more access to external resources, in turn leading to improved performance.

The RDT holds that external resources affect behaviours of organisations and that organisations could strategically make use of external resources to improve their performance (Pfeffer \& Salancik, 1978). In the context of hybrid firms, when state ownership increases, the state can take a higher proportion of dividends (profits) from the firms. As such, the state becomes more willing to grant support and offer special treatments to such firms. This support could be in the form of business opportunities. Although the extant literature does not offer direct evidence comparing access to business opportunities between hybrid firms having different degrees of state ownership, we do find some evidence showing that stateowned or state-affiliated private firms are offered more and better business opportunities.

For example, in their study of almost 2 million firm observations in the private and state sectors in China over the period of 1988-2007, Du et al. (2014) find strong and consistent evidence of systematically uneven business opportunities between the two sectors. Additionally, Sharma et al. (2020) highlight that political connections exert a significant positive effect on Chinese firms' decisions to enter export markets and on their subsequent export performance. They suggest that non-market forces allow opportunities to be diverted away from allocation by the competitive market and towards the state sector. Moreover, due to their improved access to information and government support, hybrid firms may be in a better position than private firms to realise business opportunities, thereby being able to make more investments. In Vietnam, for example, Van Thang and Freeman (2009) examine 16,200 firms and evidently show that the greater the density of state-owned firms in a region is, the more favouritism they enjoy, thereby reducing the proportion of bank loans made to private companies and increasing the time it takes private firms to gain access to land.

On the basis of the above, we extend the RDT with regard to access to finance to explain why increased state ownership is positively associated with firm performance. When state ownership increases, the benefits/losses that the state obtained from hybrid firms become more significant; as such, the state has a stronger incentive to help enhance firm performance, including granting them access to external finance. Research has shown that firms having a close connection with the government enjoy better treatments in terms of bank loans (Du et al., 2015; Nguyen et al., 2006; Song et al., 2017; Van Thang \& Freeman, 2009). This strand of literature points to the possibility that when the state has a larger stake in hybrid firms (but remains less than 50\%, we will discuss the case of larger than $50 \%$ in the next section), the state is more willing to give hybrid firms more business opportunities and access to finance. These additional resources under the management and governance of entrepreneurs, who hold the majority shares of the firms, could lead to improved performance.

When state ownership increases, hybrid firms can not only obtain more sources from the governments, 
but can also utilise their enhanced legitimate identity to acquire opportunities from markets. Legitimacy is an essential dimension in the institutional theory, which highlights the importance of being socially accepted (e.g., credibility) to firm survival and growth (Suchman, 1995). In the context of hybrid firms, their government-backed identity may persuade and enable clients and suppliers of their credibility to sign longer-term or higher-value contracts. For example, firms that have state ownership of $40 \%$ may find it easier to signal business partners that they are backed by the governments than those whose state ownership only makes up $10 \%$. Also, when state ownership increases, hybrid firms may deploy their enhanced hybrid identity as a valuable asset to improve their market position and gain trust from stakeholders, in turn leading to stronger alliance relationships. In support, Chase and Murtha (2019) show that US firms that have at least one contract with a government agency, thanks to the signalling effect, are more likely to enter into further contracts with other government agencies and also with private clients. Moreover, hybrid firms may utilise their legitimacy to gain access to trade credits and informal loans. It is also noteworthy that larger state ownership indicates stronger commitment that the state puts into the hybrid firms. This has a signalling effect, which is able to reduce information asymmetries between firms and external potential resource holders, and thus facilitate firms' access to external finance ( $\mathrm{Li}$ et al., 2019), including trade credits (Agostino \& Trivieri, 2014) and informal debts (Reynolds, 2011).

In light of the RDT and legitimacy viewpoint, it could be expected that when state ownership increases, hybrid firms gain more access to business opportunities, external finance, and enhanced legitimacy. Such essential ingredients will likely enable hybrid firms to improve their performance.

\subsubsection{When state ownership is more than 50\%}

While we argue that increases in state ownership are positively associated with improved performance of hybrid firms, we suspect that this relationship is non-monotonic. It is therefore argued that an excessive level of state ownership may be harmful to firm performance. The reason lies in the negative effects associated with agency problems when the share of state ownership becomes too large. Specifically, when state ownership in a hybrid firm exceeds $50 \%$, it is the state rather than the entrepreneur who makes all decisions for the firm. In this situation, firm performance may not be as good as it is when state ownership remains below 50\%. This happens because of agency problems.

The first agency problem occurs between entrepreneurs and the state. Specifically, entrepreneurs who are minority shareholders compared to the state receive a smaller proportion of distributed profits earned from running the business. This fact makes entrepreneurs less motivated to contribute to higher performance and success of the firm. This agency problem inevitably leads to deficient outcomes (Wehrheim, Dalay, Fosfuri, \& Helmers, 2020) because entrepreneurs' contributions are the main driver of firm performance (Song et al., 2015). The second agency problem, which is well-documented in the extant literature, occurs between a government official running a hybrid firm and the state. The government official may extract private benefits from running the firm instead of maximising its profits or share values. This opportunistic behaviour exists because of the incompleteness in the monitoring systems of the state (O'Toole et al., 2016) and the government official's lack of professional management skills, given that he or she is often appointed by the administration (Gan, Guo, $\& \mathrm{Xu}, 2017)$. With the majority of ownership, the stake of the state in hybrid firms is relatively large. In the presence of weak institutions, the government officials are therefore relatively free to extract private benefits from running the firms. Taking altogether, we propose the following hypothesis:

Hypothesis H2: For hybrid firms, the association between state ownership and firm performance follows a non-linear pattern.

\subsection{Local governance quality and state governance}

In this section, we focus on the association between hybrid ownership and firm performance in relation to institutional settings. The first institutional dimension of investigation is local governance quality; and the second is the intervention of the government in hybrid firms. 


\subsubsection{Local governance quality}

Local governance quality - a dimension of institutions-indicates the execution and implementation of national legislation and other formal institutional arrangements at the local (e.g., provincial) level (Nguyen et al., 2018). Specifically, Williamson (2000) argues that the play of the game (the execution of formal institutions) is even more important than the rules of the game (the formal institutional framework per se) because no rule of law can become effective in practice unless backed up by a set of efficient governance systems.

In the context of Vietnam, the quality of governance across regions varies significantly due to the impact of the nation's history (Mirza \& Giroud, 2004). While in North Vietnam, the institutions were initially built following the pure socialist blueprint, South Vietnam only transformed from capitalism in 1975. This historical event contributes significantly to the differences in local institutions of governance across regions of Vietnam (Makino \& Tsang, 2011). Moreover, these institutions of governance are rather sticky despite the unification of the two states four decades ago, which instituted a single formal framework across the nation (Nguyen et al., 2018).

In addition, the variations in local governance quality have been magnified due to the extensive decentralisation in the Doimoi (economic renovation) (Lan Phi \& Anwar, 2011). The foundation of this program was the promulgation of the 1996 (revision in 1998) State Budget Law, which grants local governments sufficient autonomy in their fiscal strategies. Local authorities are considerably independent of the central government in their revenue and expenditure decisions. Further to this, they have substantial freedom to determine their local regulatory arrangements, which create substantial heterogeneity in the governance quality across regions in Vietnam (Anwar \& Nguyen, 2014; Schmitz et al., 2015).

Meanwhile, local governance quality is crucial to small firms because these firms typically operate within the boundary of local markets, which are strongly shaped by the governance arrangements of local authorities rather than the very broad general national institutions (Du \& Mickiewicz, 2016; Nguyen \& Canh, 2020). In this regard, hybrid ownership may serve as a strategic political connection that helps firms build relationships with local authorities.
In a biased institutional environment (i.e., one that is geared towards benefiting state-owned enterprises) gaining legitimacy (i.e., being treated as a (partial) state-owned firm) is particularly essential to ensure that firms are exempted from corruption and unproductive interventions from government agencies, or even to allow them to enjoy favourable treatments from local authorities.

Empirical evidence suggests that firms with a strong political affiliation (i) experience better de facto protection of their private properties (Zhou, 2017), (ii) are less sensitive to corruption (Nguyen \& van Dijk, 2012), and (iii) are exempted from bureaucratic interventions from local government agencies (Nguyen, 2019). Therefore, it could be expected that when local governance quality is lower, the effect of state ownership on protecting firms against corruption and bureaucratic governance becomes stronger. In contrast, when local governance quality is higher (more effective), the effect of state ownership becomes less substantial since firms in all sectors have a fair access to information, opportunities, and resources. This strand of arguments points to the possibility that state ownership may substitute the effects of improved governance quality. As such, we hypothesise:

Hypothesis H3a: Local governance quality moderates the association between state ownership in hybrid firms and their performance.

\subsubsection{The involvement of the state}

In this section, we argue that the break in governance efficiency may happen even before state ownership reaches $50 \%$ if the government is allowed to become involved in the governance of hybrid firms. This can occur when entrepreneurs who own the majority (greater than $50 \%$ ) of equity shares of a hybrid firm decide to let the government (in this case, the minor shareholder) become involved in business governance. The purpose of this decision is to further enhance their political affiliation status and improve firm legitimacy with a view to gaining additional preferential treatments such as subsidies and lower tax rates (Du et al., 2015). In this regard, the state (the government official appointed to represent the state) instead of the entrepreneur has the final voice in the governance of the firm. This arrangement, 
unfortunately, may have a negative impact on firm performance for several reasons.

First, appointed officials may not possess adequate skills in governance and management of business operations needed to do their jobs. Unlike entrepreneurs who need to build their business from scratch, the appointed officials usually hold their positions in the public administration system before being appointed to a business (Nguyen et al., 2018). As such, they tend to employ the governance style of running a unit of government agency to the business, which may not work well for business activities. Second, the appointment is term-based, which typically lasts 5 years before the official being rotated to another position in a different organisation (Lan Phi \& Anwar, 2011). Since the officials are not in charge of their performance outcomes after the appointment term, they are not incentivised to maximise firm long-term value but are more likely to concentrate on extracting rents from running the firm. This agency cost, which originated from the nature of the appointment system, reinforces our argument that the involvement of the government in the governance of hybrid firms may reduce firm performance.

More importantly, the involvement of the government may further deteriorate the benefit associated with state ownership in a hybrid firm. It is noteworthy that the benefit associated with state ownership is primarily the firm's access to key strategic resources owned by the state. However, the appointed official may fail to build a system of efficient governance to utilise these resources. For example, the governance system under the leadership of the appointed official may be distracted from pursuing economic goals (but political goals, for example), or may be inefficient in transforming resources into competitive advantages (due to the lack of managerial skills or the rent-seeking behaviours) (Du \& Girma, 2012; Nguyen, 2019). This unproductive governance system is thus expected to reduce the positive impacts of additional resources obtained from state ownership on firm performance. In support, Song et al. (2015) evidently show that in Chinese listed hybrid corporates, the positive impact of state ownership on firm performance becomes less prominent when the corporate governance is more politically inclined. Also, in the context of Vietnam, De Jong et al. (2012) show that although political connections allow firms to foster a network of informal relationships with public officials, and reap the accompanying benefits, they may have such disadvantages as an inefficient allocation of resources, which leads to reduced firm performance. As such, we propose:

Hypothesis H3b: For hybrid firms that have a percentage of state ownership that is less than 50\%, there is an association between the involvement of the government in firm governance and firm performance.

Hypothesis H3c: For hybrid firms that have a percentage of state ownership that is less than 50\%, the involvement of the government in firm governance moderates the association between state ownership and firm performance.

Before introducing the data for analysis and the empirical estimations, we summarise the proposed hypotheses in Fig. 1.

\section{Data and method}

\subsection{Data}

The empirical setting of this study is Vietnam-a transition economy. The country has a large number of small and very small firms (e.g., household businesses) operating in an underdeveloped and incomplete institutional environment (Nguyen \& Canh, 2020; Tran, 2019) that fits well into the theoretical settings of this study. To test the proposed hypotheses, we employ the Annual Enterprise Survey (AES) dataset provided by the Vietnam General Statistics Office (GSO). The survey was first conducted in 2000, and the dataset has been updated annually since then. By the statistics regulation of Vietnam, all businesses having more than 10 employees must take part in the survey. For businesses with fewer than 10 employees, a sample is randomly selected to participate in the survey. The scope of the survey comprises both manufacturing and service industries, and includes all types of ownership, including private, state-owned, hybrid, and foreign-owned.

The AES panel data that we obtained from GSO is 19 years, from 2000 to 2018 . However, the period of analysis in this study is unfortunately scaled down to 13 years, from 2006 to 2018 . The reason is that: first, it is only from 2006 that the information about hybrid ownership is fully reported; second, the data must 
Fig. 1 Analytical framework. Hypothesis H1, which is not presented in the analytical framework, investigates the performance of firms based on their general ownership structures (i.e., private firms, state-owned firms, and hybrid firms)

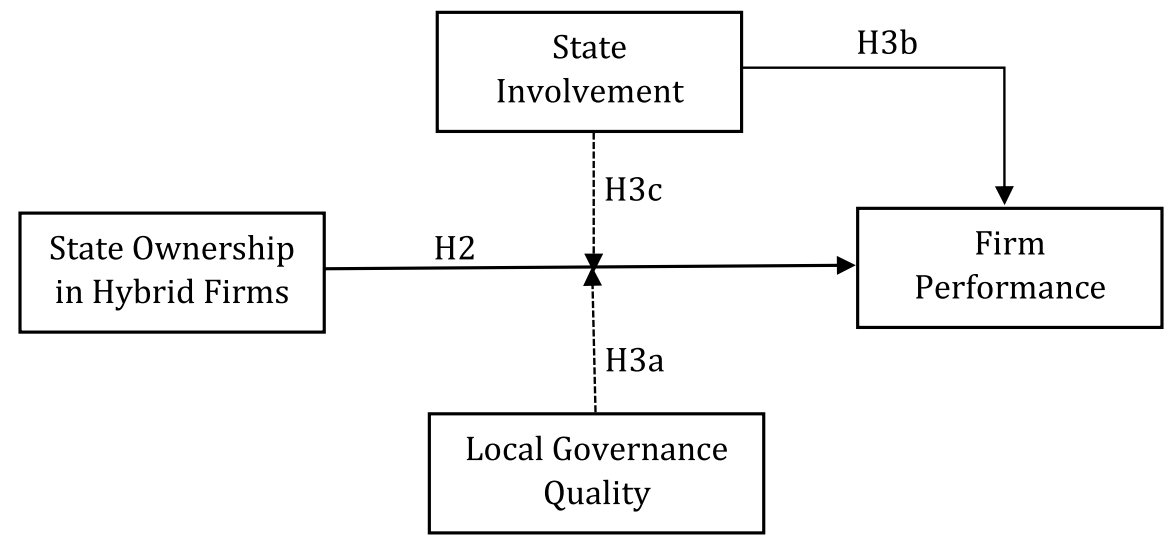

match with the second dataset taken from the Provincial Competitiveness Index (CPI), a joint product of the Vietnam Chamber of Commerce (VCCI) and the US Agency for International Development (USAID). PCI is a panel of provincial governance quality. The quality index is scored from 0 to 100 , and the higher score means the better quality of governance, such as corruption controls, land access, leadership proactivity, and administration transparency. The PCI index is calculated based on a survey of more than 15,000 private firms and 1500 foreign-owned firms operating across 63 provinces in Vietnam. From 2006, the PCI index has been reported for all provinces annually.

We combine the AES dataset with the PCI dataset to create a panel of 13 years. Before analysing the data, we conduct some initial cleaning to avoid biases. Specifically, we drop all observations that have meaningless accounting reports such as negative number of employees and zero assets. We control the outliers by censoring the top and bottom $1 \%$ of observations in each continuous variable. We understand that the three categories of business ownership is over-simplified since in reality, state-own firms may be owned by several branches of governments (e.g., local government vs central governments); also, private firms are a group of businesses of different legal forms (e.g., limited liability company, joint-stock company, and partnership). However, to explore the impacts of hybrid ownership, the simple model of three categories of firm ownership is arguably most appropriate. Also, we are aware that firms that have both stateowned and private ownership may be either privatised state-owned firms or hybrid firms. To reduce the possibility that the former is also included in our sample, we excluded large firms since privatised state-owned firms are usually large corporations (O'Toole et al.,
2016). After doing so, we find no firms changing their ownership between private, state-owned, and hybrid in the study period. This indicates that the hybrid (small) firms under investigation are born-hybrid (i.e., not being hybrid because of privatisation). After applying these exclusions, the final sample in our study thus includes 1,093,613 firm-year observations, in which 20,633 are hybrid.

\subsection{Variables and summary statistics}

\subsubsection{Dependent variable}

The dependent variable of interest is firm performance. For the sake of robustness, we measure firm performance using two variables: revenues and profits. Revenue is a proxy for a firm's market-based performance relative to its peers in the same industry. Firms with higher market shares (i.e., more revenues) enjoy several competitive advantages, such as better brand recognition, higher brand values, more business opportunities, and stronger market powers (Diewert \& Nakamura, 2007). Profits, on the other hand, represent the efficiency of firm governance. Firms with higher profits ceteris paribus have a more efficient cost function, which could result from stronger managerial capital (Diewert \& Nakamura, 2007). In this study, both revenues and profits are normalised using firm total assets.

\subsubsection{Independent variables}

The key independent variable of interest is the percentage of state ownership in hybrid firms. It is noteworthy that state ownership is a continuous variable and must be greater than 0 and smaller than 100 
(otherwise a firm would be either private or stateowned). Hybrid firms that have less than $50 \%$ of state ownership may nevertheless decide to let the government become involved in their business governance. As such, government involvement is a dummy variable, which takes value 1 if the government takes the lead in the governance of the firm, and 0 otherwise. This information is reported by individual firms in the survey.

\subsection{Control variables}

Following the extant literature, we include a set of covariates that may influence firm performance. At the firm-level, we control for firm size, firm age, firm investment and industry. These variables represent firm-specific and industry-specific characteristics that significantly determine both economic performance and productivity performance (Valliere \& Peterson, 2009; Zhou, 2017).

At the entrepreneur level, we control for owner age. This individual-specific factor plays an essential role in determining firm performance because it indicates the extent of the entrepreneur' experience, and to some extent, education which may markedly influence his or her ability to run a business (Nguyen, 2018). It is noteworthy that other time-invariant characteristics associated with entrepreneurs that may have influences on firm performance such as management styles and working experience before start-up will be controlled by the fixed-effects which will be introduced in the next section.

At the provincial level, we take into account the governance quality of local governments, which is measured using the PCI index. This index is a combination of nine sub-indices, each evaluating a dimension of local government, such as controls for corruption, levels of transparency in public services, and the leadership proactivity of local authorities. Details of the nine sub-indices are presented in Appendix Table 6. The PCI score ranges from 0 to 100; the higher score means the better quality of local government. The methodology of the index is introduced in Appendix 4. In the study period, the average PCI score is 58. However, one province's score may be as low as 36, while another may achieve as high as 77 . These statistics show that there is substantial heterogeneity in the quality of governance of local governments across provinces in Vietnam.
The definition and summary statistics of all variables are presented in Table 1. For the sake of comparison, we present the statistics for hybrid firms, private firms, and state-owned firms, respectively. The pairwise correlation matrix is presented in Appendix Table 7.

\subsection{Specification and estimation}

Based on the conventional firm performance models, we propose the following expanded reduced-form equation. This is our baseline specification:

$$
\begin{aligned}
\text { Performance }_{i g t}= & \beta_{0}+\beta_{1}\left(\text { Firmcontrol }_{i g t}\right)+\beta_{2}\left(\text { Ownercontrol }_{\text {igt }}\right) \\
& +\beta_{3}\left(\text { Provincecontrol }_{g t}\right)+\beta_{4}\left(\text { Stateownership }_{i g t}\right) \\
& +\beta_{5}\left(\text { Governmentinvolvement }_{i g t}\right)+v_{j}+v_{t}+v_{i}+\mu_{i t}
\end{aligned}
$$

where $i$ denotes an individual firm, $g$ is the province, and $t$ a year. Therefore, Performance ${ }_{i g t}$ is either revenues or profits that firm $i$ in province $g$ achieves in year $t$. The term Firmcontrols igt $_{\text {in }}$ is comprised of the variables firm age, labour size, and investment; the term Ownercontrol $_{i g t}$ is the owner age variable; and Provincecontrols $s_{g t}$ is the PCI score.

In addition, the equation includes an industry-specific component $v_{j}$ and a time-specific component $v_{t}$, which are controlled by corresponding dummies. The term $v_{i}$ represents all time-invariant, firm-specific factors that may influence firm performance. Finally, $\mu_{i t}$ is the idiosyncratic error.

We employ the random-effects (RE) method to compare the performance of hybrid firms, stateowned, and private firms. This is because no firms jump across the three groups in our sample. Then, we use a fixed-effects (FE) method to estimate the specifications related to the performance of hybrid firms. The FE technique is able to control for unobservable time-invariant firm-level characteristics such as management and organisational culture (Nguyen, 2019); as such, it could, to some extent, reduce concerns about endogeneity due to missing variables. Also, to moderate concerns about the reverse effects from control variables to the dependent variable (firm performance), we lag firm size and firm investment one year. Moreover, we take into account the multi-level structure of the dataset by clustering the standard errors to the provincial level as well. Finally, we also conduct the variance inflation factor (VIF) tests of multicollinearity. 
Table 1 Variable definition and summary statistics

\begin{tabular}{|c|c|c|c|c|}
\hline Variable & Definition & Private & Hybrid & State-owned \\
\hline Revenues & Firm sales revenues divided by firm total assets & $1.038 * * *$ & 1.814 & $1.533 * * *$ \\
\hline Profits & Firm profits divided by firm total assets & $0.024 * * *$ & 0.058 & 0.059 \\
\hline State ownership & The percentage of state ownership in a firm & $0 * * *$ & 0.337 & $1 * * *$ \\
\hline State governance & $\begin{array}{l}\text { Take value } 1 \text { if the government involve in the governance of the } \\
\text { hybrid firms, } 0 \text { otherwise; only applicable to hybrid firms that have } \\
\text { less than } 50 \% \text { of state ownership }\end{array}$ & NA & 0.121 & NA \\
\hline Owner age & Age of the owner of a firm & $42.386^{* * *}$ & 48.336 & $51.708 * * *$ \\
\hline Firm age & Years since firm establishment & $6.211 * * *$ & 10.956 & $16.428 * * *$ \\
\hline Firm size & $\begin{array}{l}\text { Log of the number of employees (reported here the number of } \\
\text { employees) }\end{array}$ & $19.513 * * *$ & 68.492 & $89.953 * * *$ \\
\hline Local governance quality & The Provincial Competitiveness Index & $60.677 * * *$ & 59.416 & $58.073 * * *$ \\
\hline Observations & & $1,056,454$ & 20,633 & 16,526 \\
\hline
\end{tabular}

The price value is the 2010 price. The statistics reported are the mean values. The two-tailed $t$-tests comparing private firms and state-owned firms to hybrid firms show that all statistics (except profits) are significantly different between the two pairs of groups (hybrid firms serve as the benchmark)

${ }^{*}$ Significant at $10 \%$

${ }^{* *}$ Significant at $5 \%$

**** Significant at $1 \%$

\section{Results}

\subsection{Main results}

Regression results are presented in Table 2 to Table 5. The VIF tests suggest there is no significant multicollinearity in our specifications. Table 2 shows the results comparing the performance of the three types of firms: private, hybrid, and state-owned. Since the sample under investigation includes only firms that do not change their ownership types between the three groups in the study period, we employ the random-effects (RE) technique to estimate the coefficients associated with state-owned firms and private firms (the group of hybrid firms was set as the benchmark). The results show that hybrid firms consistently achieve better revenues and profits (relatively to their total assets) compared to state-owned firms and private firms. Figure 2 illustrates this finding graphically. Hypotheses H1 is thus supported.

Turning to the effect of state ownership on hybrid firm performance, we move to Table 3. To facilitate the interpretation, the variable state ownership (as a percentage) is multiplied by 100 . The coefficients associated with state ownership variable in columns 2 to 4 are positive and statistically significant, confirming our initial expectation that an increase of state ownership in hybrid firms boosts performance. For
Table 2 Hybrid firms, private firms, and state-owned firms

\begin{tabular}{lll}
\hline & $(1)$ & $(2)$ \\
& Revenues & Profits \\
\hline State-owned firms & $\mathbf{- 0 . 1 6 9 * * *}$ & $\mathbf{- 0 . 0 2 3} * * *$ \\
& $(0.031)$ & $(0.002)$ \\
Private firms & $\mathbf{- 0 . 1 7 4 * * *}$ & $\mathbf{- 0 . 0 0 9 * * *}$ \\
& $(0.051)$ & $(0.003)$ \\
Owner age & $0.471^{* * *}$ & $0.017 * * *$ \\
& $(0.047)$ & $(0.002)$ \\
Firm age & $2.401 * * *$ & $0.148^{* * *}$ \\
& $(0.138)$ & $(0.007)$ \\
Firm size & $0.176^{* * *}$ & $0.004^{* * *}$ \\
Investment & $(0.004)$ & $(0.000)$ \\
& $0.208^{* * *}$ & $-0.017 * * *$ \\
Local governance quality & $(0.010)$ & $(0.001)$ \\
& $0.122^{* * *}$ & $0.005^{* * *}$ \\
VIF & $(0.006)$ & $(0.000)$ \\
Observations & 2.521 & 2.632 \\
R-squared & $1,093,613$ & $1,093,613$ \\
\hline
\end{tabular}

The estimator is random effects (RE). All estimations include full sets of two-digit industry dummies, and 13-year dummies. The figures reported in parentheses are heteroskedasticity robust standard errors, clustered by province.

*Significant at $10 \%$

${ }^{* *}$ Significant at $5 \%$

${ }^{* * * *}$ Significant at $1 \%$ 
Fig. 2 Revenues performance of three types of ownership

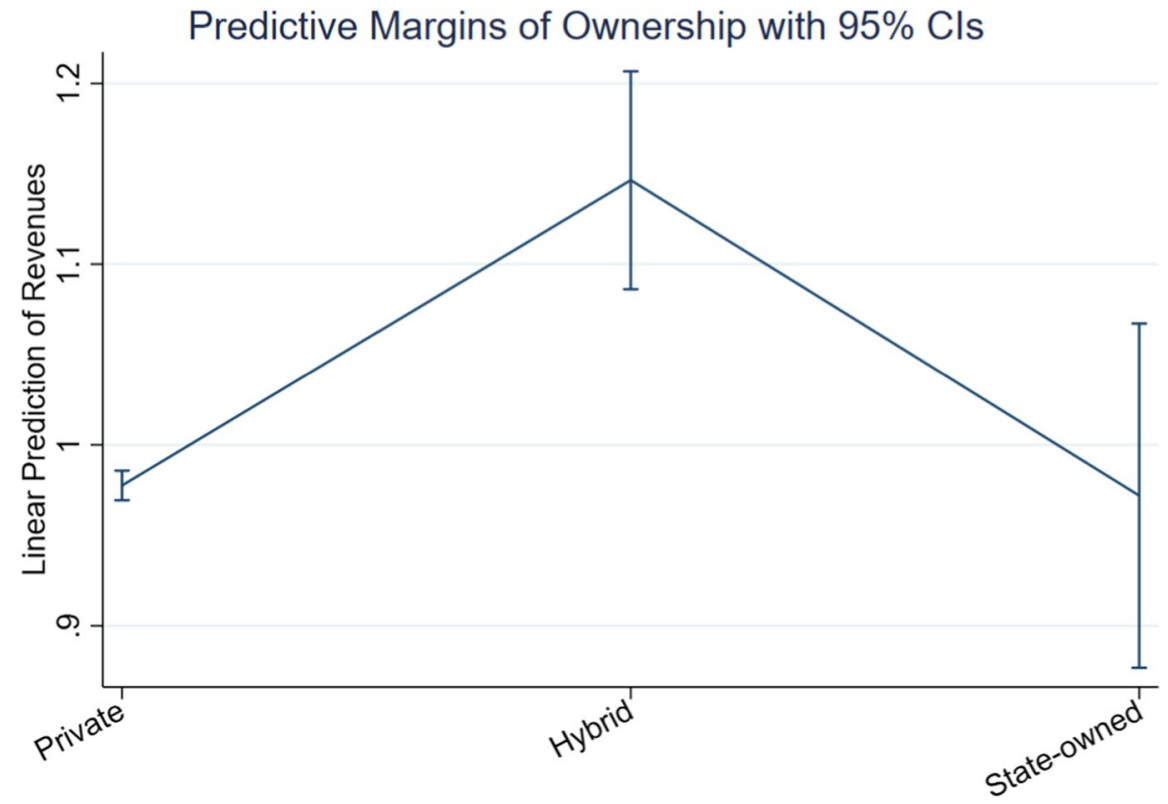

example, let's take the specifications in column 1 and 2 as examples, the results show that when state ownership is doubled, revenues increase by $43.4 \%$ and profits by $2.9 \%$, holding all else constant. However, since we expect this relationship to be non-monotonic, we further explore the coefficients associated with the squared term of state ownership (columns 3 and 4, Table 3). The coefficients are negative and statistically significant. This finding initially supports the inverted U-shaped relationship between state ownership and performance in hybrid firms. Using the coefficients associated with state ownership and its squared terms, we calculate the transition points, which are $87 \%$ of state ownership for revenues to start reducing and $42 \%$ of state ownership for profits accordingly.

For robustness checks, we also run regressions for subsamples of hybrid firms that have less than $50 \%$ of state ownership (columns 5 and 6) and more than 50\% of state ownership (columns 7 and 8). The results show that the coefficients associated with state ownership are positive and statistically significant in the specifications of state ownership that are less than 50\% while they are negative or insignificant in the specifications of state ownership that are equal to or greater than $50 \%$. To illustrate the non-monotonic effect of state ownership, we present the marginal graphs in Figure 3a (revenues) and $3 b$ (profits). The graphs show that when state ownership is low, an increase in state ownership is positively associated with firm performance. However, when state ownership is high, its positive effect gradually disappears or even turns negative. Given these findings, hypothesis $\mathrm{H} 2$ is supported.

In terms of the moderating effects of local governance quality, Table 4 shows the results. The coefficients associated with the interaction term between state ownership and local governance quality are negative (columns 1 and 3) and statistically significant (column 1), indicating that the effect of state ownership and the effect of governance quality are substitutive: when local governance equality is lower, the effect of state ownership is higher. Figure 4a illustrates this relationship graphically. Specifically, when local governance quality is higher, the positive impact of state ownership on hybrid firm revenues appears less significant (the dashed line). However, when local governance quality is lower, the relationship between state ownership and revenues becomes stronger (the steeper slope of the solid line). We expect that this pattern is valid not only for the linear relationship but also for the inverted U-shaped relationship. As such, we also examine the coefficients associated with the interaction between the squared term of state ownership and local governance quality. To illustrate the effect in a more straightforward manner, we draw the marginal graph (Figure $4 b$ ). Coupled with the linear effect, the figure shows that the inverted U-shaped relationship between state ownership and revenues in hybrid firms is stronger in weaker governance and vice versa. 
Table 3 Effects of state ownership on firm performance

\begin{tabular}{|c|c|c|c|c|c|c|c|c|}
\hline & (1) & (2) & (3) & (4) & $(5)$ & (6) & (7) & (8) \\
\hline & \multicolumn{2}{|c|}{$\begin{array}{l}\text { Total sample linear } \\
\text { model }\end{array}$} & \multicolumn{2}{|c|}{$\begin{array}{l}\text { Total sample non-linear } \\
\text { model }\end{array}$} & \multicolumn{2}{|c|}{ State ownership $<50 \%$} & \multicolumn{2}{|c|}{ State ownership $\geq 50 \%$} \\
\hline & Revenues & Profits & Revenues & Profits & Revenues & Profits & Revenues & Profits \\
\hline State ownership & $\begin{array}{l}\mathbf{0 . 4 3 4} * * * \\
(0.077)\end{array}$ & $\begin{array}{l}\mathbf{0 . 0 2 9} * \\
(0.017)\end{array}$ & $\begin{array}{l}\mathbf{1 . 0 0 5} * * * \\
(0.258)\end{array}$ & $\begin{array}{l}\mathbf{0 . 0 8 6} * * * \\
(0.011)\end{array}$ & $\begin{array}{l}\mathbf{0 . 7 4 6} * * * \\
(0.183)\end{array}$ & $\begin{array}{l}\mathbf{0 . 0 3 8} * * * \\
(0.010)\end{array}$ & $\begin{array}{l}\mathbf{0 . 0 1 8} \\
(0.228)\end{array}$ & $\begin{array}{l}-\mathbf{0 . 0 4 1} * * * \\
(0.009)\end{array}$ \\
\hline State ownership $^{2}$ & & & $\begin{array}{l}-\mathbf{0 . 5 7 7} * \\
(0.315)\end{array}$ & $\begin{array}{l}-\mathbf{0 . 1 0 2} * * * \\
(0.012)\end{array}$ & & & & \\
\hline Owner age & $\begin{array}{l}0.067 * \\
(0.036)\end{array}$ & $\begin{array}{l}0.004 * * \\
(0.002)\end{array}$ & $\begin{array}{l}0.140 \\
(0.212)\end{array}$ & $\begin{array}{l}0.054 * * * \\
(0.010)\end{array}$ & $\begin{array}{l}0.571 * \\
(0.302)\end{array}$ & $\begin{array}{l}0.032 * \\
(0.017)\end{array}$ & $\begin{array}{l}-0.472 \\
(0.380)\end{array}$ & $\begin{array}{l}0.064 * * * \\
(0.018)\end{array}$ \\
\hline Firm age & $\begin{array}{l}0.446 * * \\
(0.213)\end{array}$ & $\begin{array}{l}0.045 * * \\
(0.021)\end{array}$ & $\begin{array}{l}-0.514 * * * \\
(0.181)\end{array}$ & $\begin{array}{l}0.005 \\
(0.008)\end{array}$ & $\begin{array}{l}-1.089 * * * \\
(0.287)\end{array}$ & $\begin{array}{l}0.032 * \\
(0.017)\end{array}$ & $\begin{array}{l}0.010 \\
(0.303)\end{array}$ & $\begin{array}{l}-0.000 \\
(0.012)\end{array}$ \\
\hline Firm size & $\begin{array}{l}-0.203 \\
(0.181)\end{array}$ & $\begin{array}{l}0.016 \\
(0.016)\end{array}$ & $\begin{array}{l}0.144 * * * \\
(0.017)\end{array}$ & $\begin{array}{l}0.014 * * * \\
(0.001)\end{array}$ & $\begin{array}{l}0.281 * * * \\
(0.030)\end{array}$ & $\begin{array}{l}0.017 * * * \\
(0.002)\end{array}$ & $\begin{array}{l}0.209 * * * \\
(0.030)\end{array}$ & $\begin{array}{l}0.013 * * * \\
(0.001)\end{array}$ \\
\hline Investment & $\begin{array}{l}0.163 * * * \\
(0.017)\end{array}$ & $\begin{array}{l}0.019 * * * \\
(0.002)\end{array}$ & $\begin{array}{l}0.245^{*} \\
(0.144)\end{array}$ & $\begin{array}{l}-0.022 * * * \\
(0.006)\end{array}$ & $\begin{array}{l}0.265 * \\
(0.153)\end{array}$ & $\begin{array}{l}-0.029 * * * \\
(0.010)\end{array}$ & $\begin{array}{l}0.031 \\
(0.161)\end{array}$ & $\begin{array}{l}-0.009 \\
(0.007)\end{array}$ \\
\hline Local governance quality & $\begin{array}{l}0.044 \\
(0.081)\end{array}$ & $\begin{array}{l}-0.015 \\
(0.012)\end{array}$ & $\begin{array}{l}0.062 * \\
(0.034)\end{array}$ & $\begin{array}{l}0.002 \\
(0.002)\end{array}$ & $\begin{array}{l}0.075 \\
(0.057)\end{array}$ & $\begin{array}{l}-0.001 \\
(0.003)\end{array}$ & $\begin{array}{l}0.050 \\
(0.049)\end{array}$ & $\begin{array}{l}0.002 \\
(0.002)\end{array}$ \\
\hline VIF & 3.501 & 3.694 & 5.125 & 5.991 & 3.215 & 3.658 & 4.024 & 4.524 \\
\hline Observations & 20,633 & 20,633 & 20,633 & 20,633 & 14,535 & 14,535 & 6,098 & 6,098 \\
\hline R-squared & 0.198 & 0.122 & 0.221 & 0.115 & 0.161 & 0.134 & 0.308 & 0.111 \\
\hline
\end{tabular}

The estimator is fixed effects. The variable state ownership (as a percentage) is multiplied by 100 . The variables firm size and investment are lagged 1 period. All estimations include full sets of two-digit industry dummies, and 13-year dummies. The figures reported in parentheses are heteroskedasticity robust standard errors, clustered by province

*Significant at $10 \%$

${ }^{* *}$ Significant at $5 \%$

**** Significant at $1 \%$

In terms of profits, the sign of the coefficients in columns 3 and 4 of Table 4 are consistent with those in columns 1 and 2, indicating that they follow the same pattern. However, since the coefficients are not statistically significant, we do not find strong evidence to support the moderating effects of local governance on hybrid firm profitability. A possible explanation could be that while revenues are strongly dependent on the local markets, which are a function of local governance quality, profits represent the efficiency of firm operation and management, thereby, to some extent, being under firm control and less affected by external environments. As such, hypothesis H3a is partially supported.

Table 5 presents the results of the subsample of hybrid firms that have less than $50 \%$ of state ownership, some of which may have decided to allow the government to get involved in their business governance to some extent. The coefficients associated with state governance are negative and statistically significant at
10\% (in columns 1 and 3). This finding suggests that the involvement of the government in firm governance may harm hybrid firm performance. Therefore, hypothesis H3b is supported (by weak evidence). Turning to the interaction terms between state ownership and state governance, their associated coefficients are negative (in columns 2 and 4) and statistically significant (in columns 2). These findings show that the involvement of the government in firm governance has a negative indirect effect on firm revenues via a reduction in the efficient use of state ownership. Since the corresponding coefficient in column 4 (profit specification) is not significant, hypothesis $\mathrm{H} 3 \mathrm{c}$ is supported to some extent. Figure $5 \mathrm{a}$ and $\mathrm{b}$ illustrate the marginal effects of state governance on firm performance. They demonstrate that the positive impact of state ownership almost disappears if the government is involved in firm governance.

Finally, in terms of the control variables, firm size has a positive effect on economic performance but a negative 


\section{a Marginal Effects of Non -monotonic State Ownership on Firm Revenues}

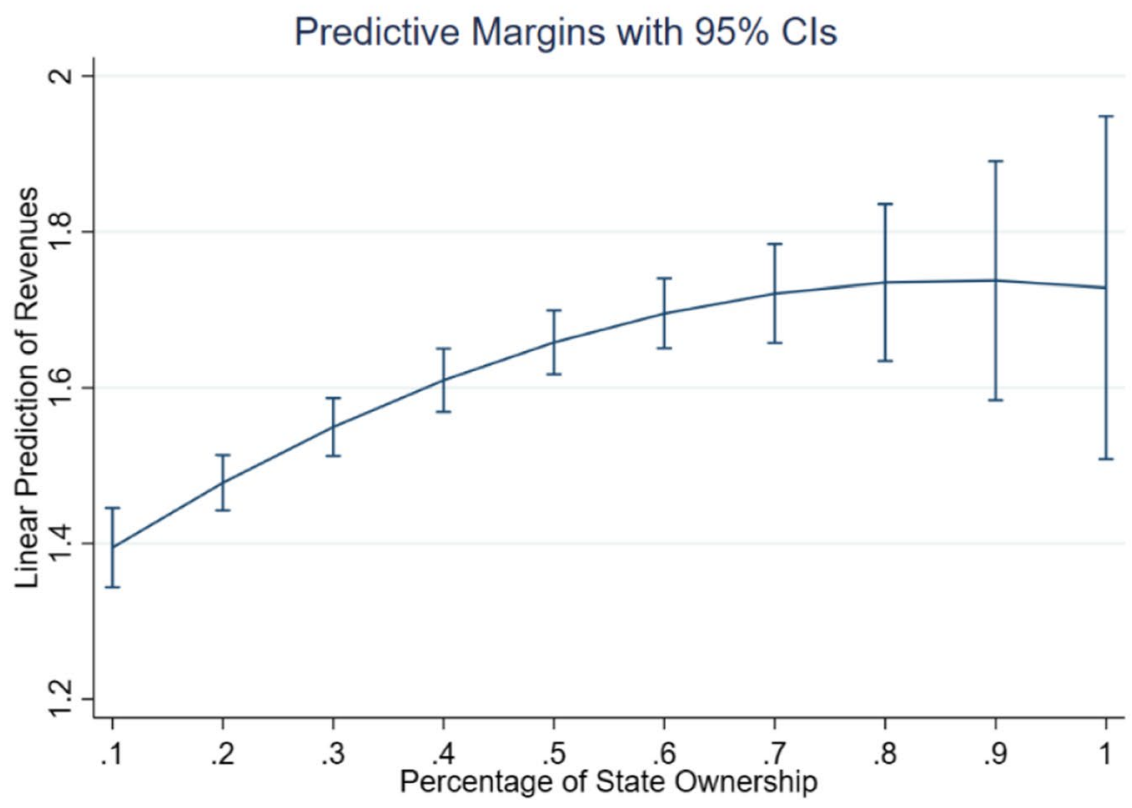

\section{b Marginal Effects of Non -monotonic State Ownership on Firm Profitability}

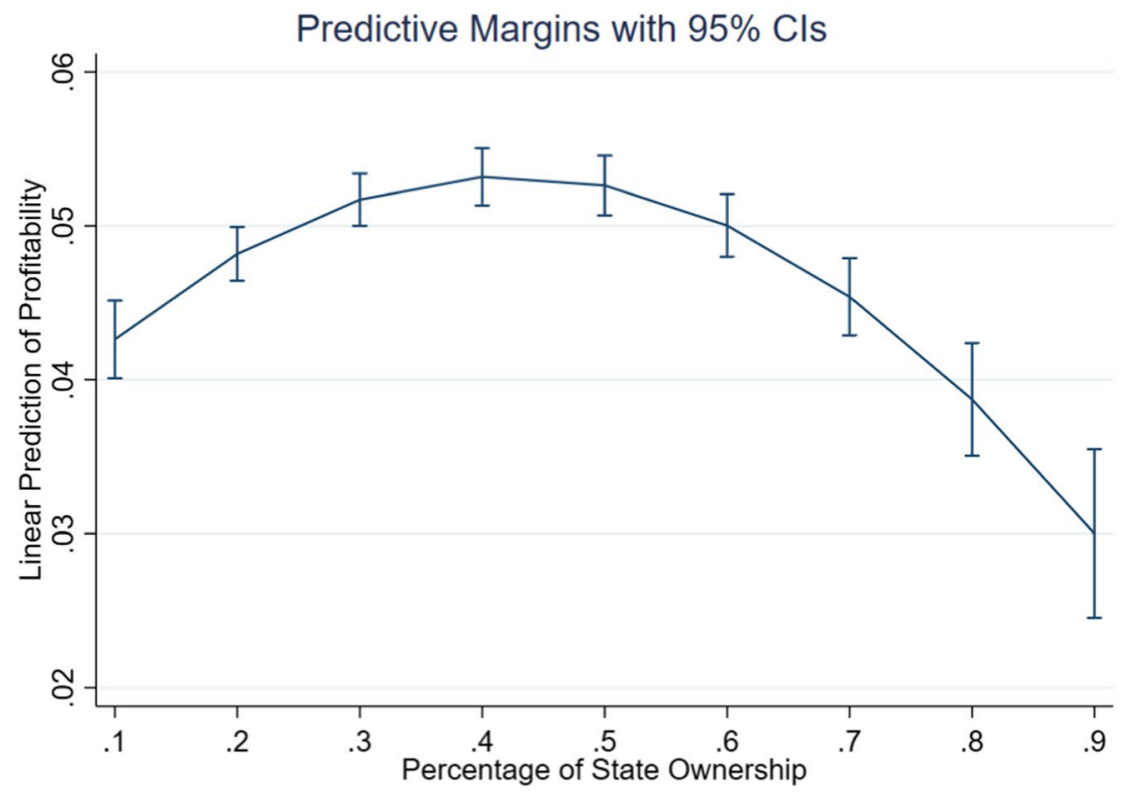

Fig. 3 a Marginal effects of non-monotonic state ownership on firm revenues. The figure illustrates the predicted values of revenues at different percentages of state ownership in a hybrid firm. State ownership is in the range of $[0,100]$ percent with 0 and 100 are excluded. b Marginal effects of non-monotonic state ownership on firm profitability. The figure illustrates the predicted values of profits at different percentages of state ownership in a hybrid firm. State ownership is in the range of $[0,100]$ percent with 0 and 100 are excluded 
Table 4 Hybrid firm performance and the impact of local governance quality
The estimator is fixed effects. The variable state ownership (as a percentage) is multiplied by 100 . The variables firm size and investment are lagged 1 period. All estimations include full sets of two-digit industry dummies, and 13-year dummies. The figures reported in parentheses are heteroskedasticity robust standard errors, clustered by province

*** Significant at $5 \%$

**** Significant at $1 \%$
*Significant at $10 \%$

\begin{tabular}{|c|c|c|c|c|}
\hline & $\begin{array}{l}(1) \\
\text { Revenues }\end{array}$ & $\begin{array}{l}(2) \\
\text { Revenues }\end{array}$ & $\begin{array}{l}(3) \\
\text { Profits }\end{array}$ & $\begin{array}{l}\text { (4) } \\
\text { Profits }\end{array}$ \\
\hline State ownership & $\begin{array}{l}\mathbf{2 . 9 4 0 * * *} \\
(0.887)\end{array}$ & $\begin{array}{l}\mathbf{1 0 . 8 8 2} * * * \\
(2.726)\end{array}$ & $\begin{array}{l}\mathbf{0 . 0 3 1} * \\
(0.018)\end{array}$ & $\begin{array}{l}\mathbf{0 . 0 2 4} \\
(0.017)\end{array}$ \\
\hline State ownership ${ }^{2}$ & & $\begin{array}{l}-\mathbf{1 0 . 7 9 6}^{* * * *} \\
(3.618)\end{array}$ & & $\begin{array}{l}-\mathbf{0 . 0 9 0} * \\
(0.048)\end{array}$ \\
\hline State ownership $\times$ local governance quality & $\begin{array}{l}-\mathbf{0 . 4 5 1} * * * \\
(0.145)\end{array}$ & $\begin{array}{l}\mathbf{0 . 3 8 2} * * * \\
(0.086)\end{array}$ & $\begin{array}{l}\mathbf{- 0 . 0 3 2} \\
(0.023)\end{array}$ & $\begin{array}{l}\mathbf{0 . 0 0 3} \\
(0.002)\end{array}$ \\
\hline State ownership ${ }^{2} \times$ local governance quality & & $\begin{array}{l}-1.648 * * * \\
(0.447)\end{array}$ & & $\begin{array}{l}-\mathbf{0 . 0 2 7} \\
(0.023)\end{array}$ \\
\hline Local governance quality & $\begin{array}{l}0.252 * * * \\
(0.072)\end{array}$ & $\begin{array}{l}1.628 * * * \\
(0.591)\end{array}$ & $\begin{array}{l}0.004 * * \\
(0.002)\end{array}$ & $\begin{array}{l}0.102 \\
(0.062)\end{array}$ \\
\hline Owner age & $\begin{array}{l}0.637 * * \\
(0.294)\end{array}$ & $\begin{array}{l}0.588 * * \\
(0.293)\end{array}$ & $\begin{array}{l}0.044 * * \\
(0.021)\end{array}$ & $\begin{array}{l}0.043 * * \\
(0.021)\end{array}$ \\
\hline Firm age & $\begin{array}{l}-0.328 \\
(0.283)\end{array}$ & $\begin{array}{l}-0.375 \\
(0.283)\end{array}$ & $\begin{array}{l}0.016 \\
(0.016)\end{array}$ & $\begin{array}{l}0.015 \\
(0.016)\end{array}$ \\
\hline Firm size & $\begin{array}{l}0.308 * * * \\
(0.027)\end{array}$ & $\begin{array}{l}0.299 * * * \\
(0.028)\end{array}$ & $\begin{array}{l}0.019 * * * \\
(0.002)\end{array}$ & $\begin{array}{l}0.019 * * * \\
(0.002)\end{array}$ \\
\hline Investment & $\begin{array}{l}0.139 \\
(0.088)\end{array}$ & $\begin{array}{l}0.136 \\
(0.088)\end{array}$ & $\begin{array}{l}-0.015 \\
(0.012)\end{array}$ & $\begin{array}{l}-0.015 \\
(0.012)\end{array}$ \\
\hline VIF & 5.141 & 6.224 & 5.322 & 6.521 \\
\hline Observations & 20,633 & 20,633 & 20,633 & 20,633 \\
\hline R-squared & 0.186 & 0.188 & 0.123 & 0.124 \\
\hline
\end{tabular}

even with a small number of observations. The mean values of the thresholds are $73 \%$ (vary from 70 to $77 \%$ ) of state ownership in the revenue specification and $36 \%$ (vary from 35 to $37 \%$ ) of state ownership in the profit specification. These values are close to the transition points we obtained using an unbalanced panel ( $87 \%$ for revenues and $42 \%$ for profits).

\section{Discussion and concluding remarks}

For the sake of robustness, we also employ a panel data threshold fixed-effect regression technique (Wang, 2015) to test the significance of the inverted U-shaped relationship between state ownership and performance in hybrid firms. The results are reported in Appendix Table 8 and are consistent with our main findings. It is noteworthy that this method requires the panel dataset to be strongly balanced; the number of observations thus drop from 20,633 to 4,568 in conducting this analysis. As such, the results obtained from this robustness check cannot be directly compared with the main results presented above since the numbers of observations are different. However, the findings show that the thresholds we proposed exist and are significant,
Given that there is a lack of clarity about whether state ownership is essential and beneficial for hybrid firms and to what extent it may matter for firms to increase their performance, this study enhances our knowledge of this field by exploring the effect of state ownership on hybrid firm revenues and profitability. As Vietnam is unique with its institutional environment being biased towards state-owned firms but under-researched context, this context can provide valuable insights for political connections research. Utilising the RDT and legitimacy viewpoint, we argue that if private firms are to improve their survival and development opportunities, they must actively 


\section{a Marginal Effects of Local Governance Quality on Revenues (Linear interaction)}

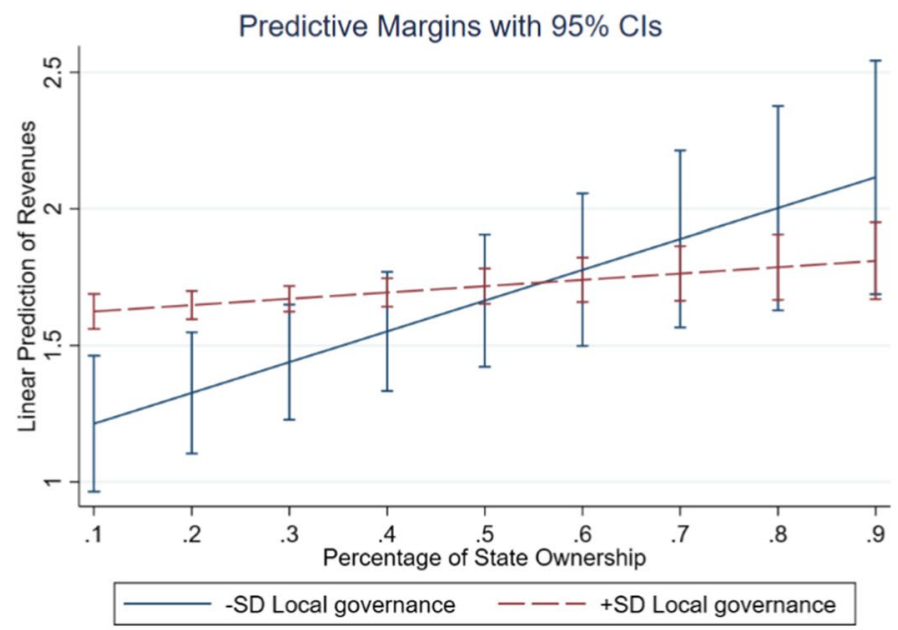

\section{b Marginal Effects of Local Governance Quality on Revenues (Non -linear interaction)}

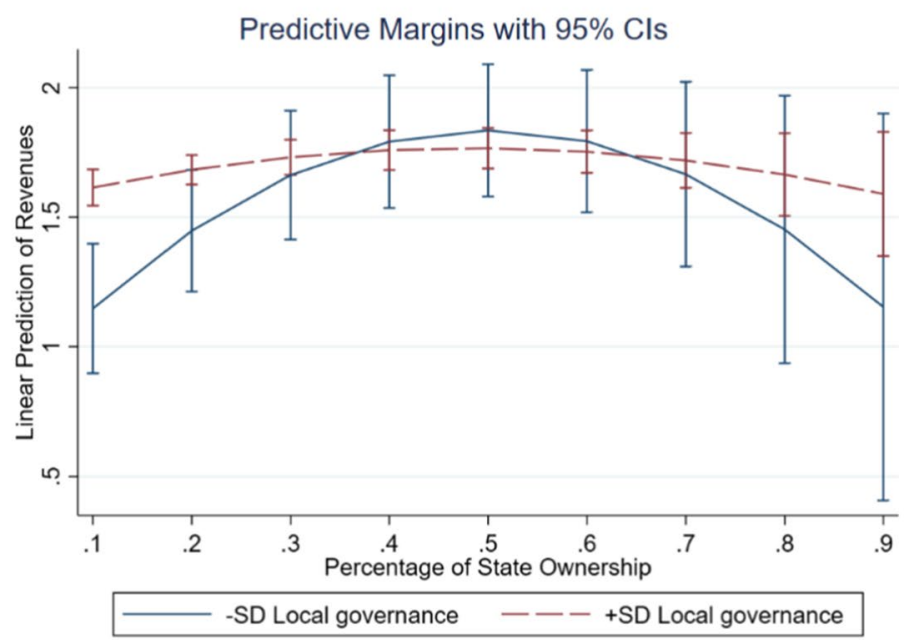

Fig. 4 a Marginal effects of local governance quality on revenues (linear interaction). The figure illustrates the predicted values of revenues of hybrid firms at different levels local governance quality. The solid line represents the predicted revenues of hybrid firms that operate in province having local governance quality lower than the mean value 1 standard deviation. The dash line represents the predicted revenues of hybrid firms that operate in province having local governance quality higher than the mean value 1 standard deviation. State ownership is in the range of $[0,100]$ percent with 0 and 100 are excluded. b Marginal effects of local governance quality on revenues (non-linear interaction). The figure illustrates the predicted values of revenues of hybrid firms at different levels local governance quality. The solid line represents the predicted revenues of hybrid firms that operate in province having local governance quality lower than the mean value 1 standard deviation. The dash line represents the predicted revenues of hybrid firms that operate in province having local governance quality higher than the mean value 1 standard deviation. State ownership is in the range of $[0,100]$ percent with 0 and 100 are excluded 
Table 5 The involvement of the government in firm governance (state ownership $<50 \%$ )

The estimator is fixed effects. The variable state ownership (as a percentage) is multiplied by 100 . The variables firm size and investment are lagged 1 period. All estimations include full sets of two-digit industry dummies, and 13-year dummies. The figures reported in parentheses are heteroskedasticity robust standard errors, clustered by province

${ }^{*}$ Significant at $10 \%$

${ }^{* *}$ Significant at $5 \%$

**** Significant at $1 \%$

\begin{tabular}{lllll}
\hline & $(1)$ & $(2)$ & $(3)$ & $(4)$ \\
& Revenues & Revenues & Profits & Profits \\
\hline State ownership & $0.946^{* * *}$ & $1.249^{* * *}$ & 0.017 & $0.046^{* * *}$ \\
& $(0.231)$ & $(0.399)$ & $(0.014)$ & $(0.016)$ \\
State governance & $\mathbf{- 0 . 1 6 0 *}$ & $\mathbf{0 . 1 6 2}$ & $\mathbf{- 0 . 0 0 9 *}$ & $\mathbf{0 . 0 0 7}$ \\
& $(0.082)$ & $(0.214)$ & $(0.005)$ & $(0.018)$ \\
State ownership $\times$ local & & $-\mathbf{1 . 2 3 5} * *$ & & $-\mathbf{0 . 0 4 2}$ \\
governance quality & & $(0.598)$ & & $(0.044)$ \\
Owner age & 0.195 & $-1.369^{* *}$ & $0.070^{* * *}$ & $0.095^{* * *}$ \\
& $(0.387)$ & $(0.631)$ & $(0.025)$ & $(0.031)$ \\
Firm age & $-0.884 * * *$ & -0.782 & 0.020 & 0.010 \\
& $(0.307)$ & $(0.497)$ & $(0.019)$ & $(0.021)$ \\
Firm size & $0.267 * * *$ & $0.225^{* * *}$ & $0.019 * * *$ & $0.020^{* * *}$ \\
& $(0.040)$ & $(0.063)$ & $(0.002)$ & $(0.002)$ \\
Investment & $0.498^{* *}$ & 0.440 & -0.008 & 0.013 \\
Local governance quality & $(0.202)$ & $(0.327)$ & $(0.014)$ & $(0.012)$ \\
& -0.043 & 0.088 & -0.001 & 0.001 \\
VIF & $(0.065)$ & $(0.100)$ & $(0.003)$ & $(0.004)$ \\
Observations & 3.214 & 4.321 & 2.921 & 4.021 \\
R-squared & 14,535 & 14,535 & 14,535 & 14,535 \\
\hline & 0.210 & 0.254 & 0.106 & 0.140 \\
\hline
\end{tabular}

exceeding level of state ownership may, however, become harmful. This study offers both theoretical and practical implications.

Looking first to the theoretical implications of our study, we focus our contributions to the entrepreneurship literature on hybrid ownership, emerging market, resource dependence theory and legitimacy viewpoint. First, it systematically investigates hybrid ownership, an increasingly popular strategy employed by entrepreneurs in developing countries to improve their connections with the governments. To our knowledge, research has yet to pay sufficient attention to entrepreneurial firms with partial state ownership, irrespective that this ownership model amounts to a political connection at an institutional level (Song et al., 2016). We believe that the effects of this type of political connections on firm performance are not weaker than the effects of other well-studied political connections at the individual level because hybrid ownership is created via an explicit, written, legal contract, based upon which the government and the entrepreneurs build an institutionalised relationship (Zhang et al., 2020). As such, this study advances early work on informal (social network-based) political connections 
by addressing a more prominent issue associated with entrepreneurial strategic planning.

Second, this study identifies a boundary in which the positive association between hybrid ownership and firm performance becomes more effective. Specifically, we show that hybrid firms are less likely to be affected by local institutional voids (such as poor governance quality). This finding helps explain the over-performance of hybrid firms against both private firms and state-owned firms. Compared to previous studies that purely focus on the impact of partial state ownership and political affiliation on access to bank loans (Du et al., 2015; Song et al., 2017), this study adds value by showing the relevance of institutional endorsement. We highlight the vital importance of partial state ownership on firm performance through an institutional viewpoint (Zhang et al., 2020).

Third, our finding suggests that hybrid ownership is not always good for entrepreneurial firms. Specifically, an unexpectedly high level of state ownership may harm firm performance. This novel finding puts a caveat on the persistent implication from the extant literature that political affiliation is always associated with benefits. We reinforce Luo et al. (2019) and Fisman et al. (2012) arguments that political relationship building can exert contradictory effects on a new venture's performance. Moreover, our results demonstrate that while state ownership is conducive to firm performance, actual involvement by the government in firm governance may be detrimental (especially to revenues and TPF). Therefore, we suggest that there is substantial heterogeneity in the types and levels of political connections. It is therefore incumbent upon entrepreneurs to evaluate the pros and cons of each strategy to make the most appropriate affiliation decision.

For organisations seeking to make the best use of the state ownership in order to enhance their performance in an emerging market like Vietnam, this study offers some key practical implications. For entrepreneurs, it may be beneficial to team up with the government for sharing business ownership. This strategy helps small firms gain access to bank loans and strategic information, and protects them from bureaucratic harassment from incomplete institutional environments. However, entrepreneurs should ensure they retain their majority power and control rights over the governance of their businesses. Thus, they can fully utilise the key strategic resources opened up to them by the hybrid form of businesses in the most appropriate and efficient manner. For policymakers, the hybrid legal form may be a better way of privatising small-sized state-owned firms than the "red hat" and rented models previously employed. Zhang et al. (2020) suggest that, as a new form of state-sector reform, mixed-ownership reform should extend beyond the privatisation of state-owned firms to operate in a reverse direction, i.e., entrepreneurs should actively seek out state ownership. As such, authorities in developing countries may consider the hybrid legal form of business ownership to be a win-win solution for both the private and state sectors in weak institutional environments.

This study is not without limitations that should be acknowledged in order to provide potential avenues for future research. First, due to data limitations, we are still unable to thoroughly separate privatised state-owned firms from hybrid firms in our sample. Even though we restrict the sample to small firms, which are much less likely to be privatised state-owned enterprises since they did not change their ownership types in the study period, there is still a possibility that the sample under investigation is not pure hybrid firms. Second, the dataset employed in this study is country-specific. One of the main weaknesses of a country-specific research design is that we only observe within-country effects, which may be influenced by social embeddedness. Future research should therefore re-test the validity of our findings using a multi-country dataset with longer survey periods. Finally, the study focuses particularly on economic performance of hybrid firms. However, other dimensions of performance such as productivity and sustainable growth are also important to evaluate the contributions of hybrid firms to the economy. Future studies should investigate these issues in more detail.

In a nut shell, entrepreneurial firms tend to exert higher political engagement and influence than established firms (Luo \& Junkunc, 2008). As such, this study examines the role of hybrid ownership as a novel form of political connections employed by SMEs to gain access to key strategic resources. The context of analysis is Vietnam-a highly relevant but unexplored empirical setting in the literature of political connections. We find that hybrid legal form boosts firm performance; however, a too high level of state ownership may exert a negative impact. This study therefore has important implications that the state should have a role to play in firm ownership but should limit its role to providing resources and staying out of the governance of the hybrid firms. 


\section{a Marginal Effects of State Involvement on Firm Revenues}

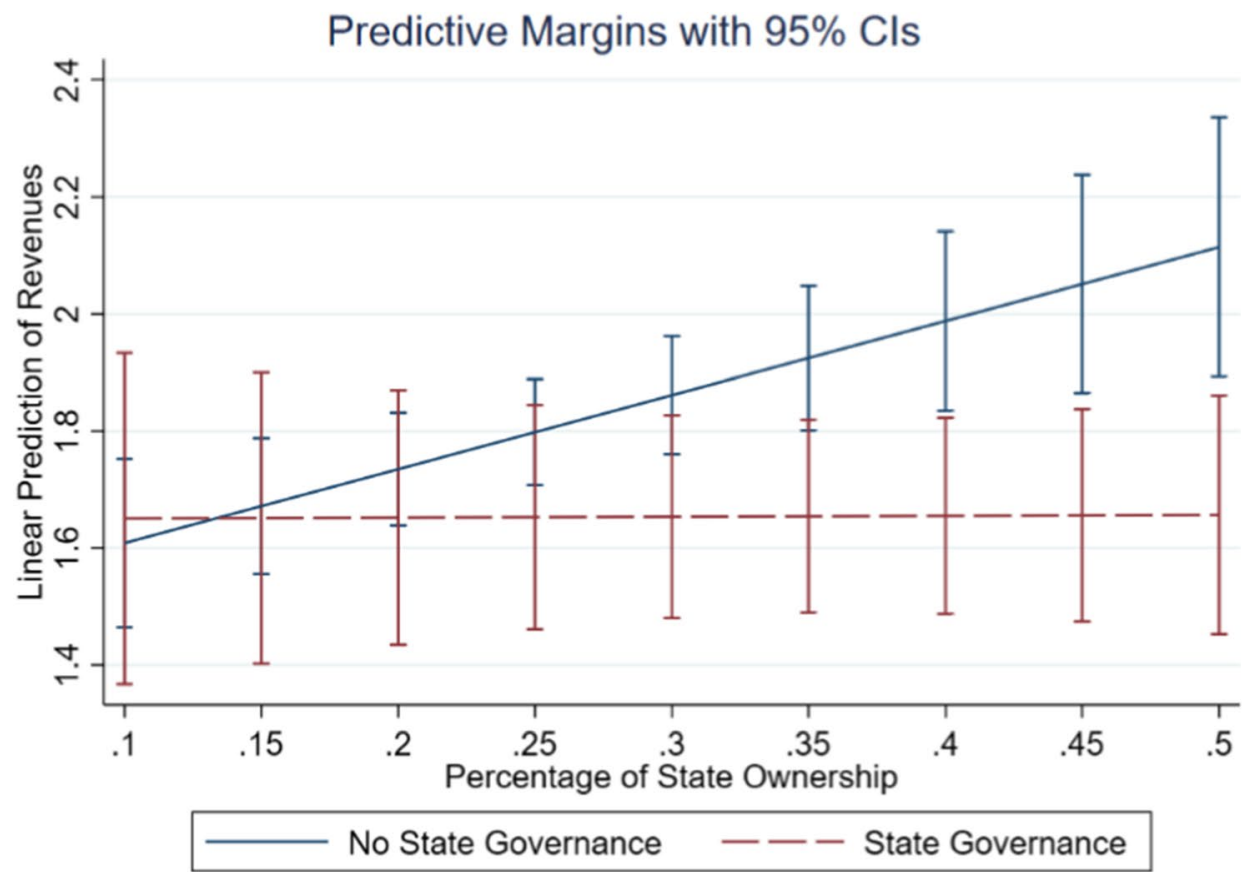

b Marginal Effects of State Involvement on Firm Profitability

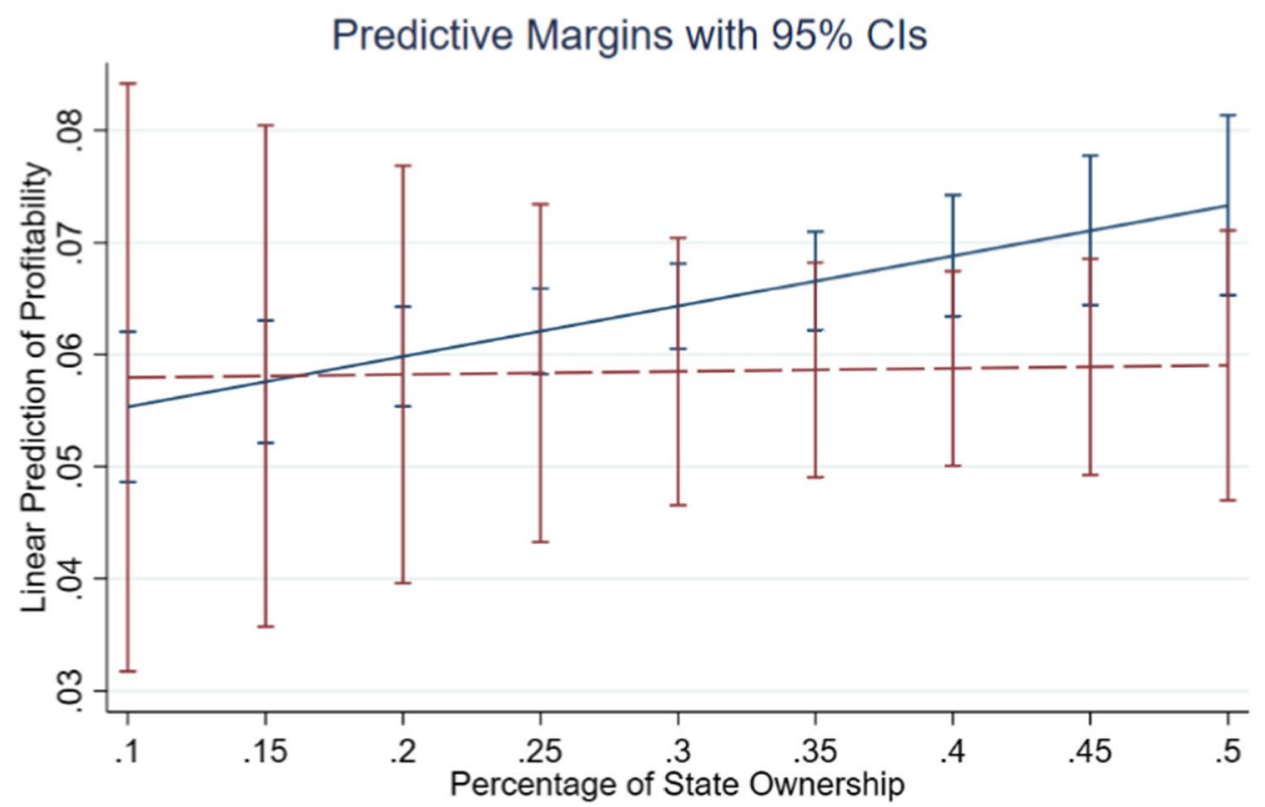

No State Governance $\quad-\quad-$ State Governance 
4Fig. 5 a Marginal effects of state involvement on firm revenues. The figure illustrates the predicted values of revenues of hybrid firms that have state governance (dash line) and hybrid firms that do not have state governance (solid line). State ownership is in the range of $[0,100]$ percent with 0 and 100 are excluded. b Marginal effects of state involvement on firm profitability. The figure illustrates the predicted values of profits of hybrid firms that have state governance (dash line) and hybrid firms that do not have state governance (solid line). State ownership is in the range of $[0,100]$ percent with 0 and 100 are excluded

\section{Appendix}

Table 6 Definition and summary statistics of PCI sub-indices

\begin{tabular}{|c|c|c|c|c|c|}
\hline Variable & Definition & Mean & S.D. & Min. & Max. \\
\hline Legal institutions & $\begin{array}{l}\text { Measures the confidence in provincial legal institutions, whether firms regard } \\
\text { provincial legal institutions as an effective vehicle for dispute resolution, or as } \\
\text { an avenue for lodging appeals against corrupt official behaviour. The indicator } \\
\text { ranges from } 1 \text { to } 10 \text {; the higher the score, the better the institutions. }\end{array}$ & 5.15 & 1.16 & 2.00 & 7.99 \\
\hline Entry costs & $\begin{array}{l}\text { Measures the differences in entry costs for new firms across provinces (for example, } \\
\text { length of business registration in days, etc.). The indicator ranges from } 1 \text { to } 10 \text {; } \\
\text { the higher the score, the lower the entry costs. }\end{array}$ & 7.97 & 0.83 & 4.96 & 9.60 \\
\hline Land access & $\begin{array}{l}\text { Combines two dimensions of the land problems confronting entrepreneurs: how } \\
\text { easy it is to access land and the security of tenure once land is acquired. The } \\
\text { variable ranges from } 1 \text { to } 10 \text {; the higher the score, the better the access. }\end{array}$ & 5.99 & 1.34 & 1.89 & 8.84 \\
\hline Time costs & $\begin{array}{l}\text { Measures how much time firms waste on bureaucratic compliance, as well as how } \\
\text { often and for how long firms must shut down their operations for inspections by local } \\
\text { regulatory agencies. The indicator ranges from } 1 \text { to } 10 \text {; the higher the score, the lower } \\
\text { the time waste. }\end{array}$ & 6.19 & 1.09 & 2.64 & 8.93 \\
\hline Business supports & $\begin{array}{l}\text { Measures provincial services for trade promotion, provision of regulatory information } \\
\text { to firms, business partner matchmaking, provision of industrial zones or industrial } \\
\text { clusters, and technological services for firms. The indicator ranges from } 1 \text { to } 10 \text {; the } \\
\text { higher the score, the better the support. }\end{array}$ & 5.14 & 1.33 & 1.40 & 9.62 \\
\hline Labour training & $\begin{array}{l}\text { Measures the efforts by provincial authorities to promote vocational training and skills } \\
\text { development for local industries and to assist in the placement of local labour. The } \\
\text { indicator ranges from } 1 \text { to } 10 \text {; the higher the score, the better the training. }\end{array}$ & 5.42 & 1.05 & 1.84 & 9.60 \\
\hline Corruption & $\begin{array}{l}\text { Measures how much firms pay in bribes, how much of an obstacle those extra } \\
\text { fees pose for their business operations, whether payment of those extra fees } \\
\text { generates the expected results or "services", and whether provincial officials } \\
\text { use compliance with local regulations to extract rents. The indicator ranges } \\
\text { from } 1 \text { to 10; the higher the score, the better the corruption controls. }\end{array}$ & 6.06 & 1.00 & 2.81 & 8.94 \\
\hline Transparency & $\begin{array}{l}\text { Measures whether firms have access to the proper planning and legal documents } \\
\text { necessary to run their businesses, whether those documents are equitably } \\
\text { available, and whether new policies and laws are communicated to firms and } \\
\text { redictably implemented. The indicator ranges from } 1 \text { to } 10 \text {; the higher the } \\
\text { score, the more transparent. }\end{array}$ & 5.64 & 1.23 & 2.14 & 8.85 \\
\hline Leadership proactivity & $\begin{array}{l}\text { Measures the creativity and cleverness of provinces in implementing central } \\
\text { policy, designing their own initiatives for private sector development, and working } \\
\text { within sometimes unclear national regulatory frameworks to assist and interpret them } \\
\text { in favour of local private firms. The indicator ranges from } 1 \text { to } \\
10 \text {; the higher the score, the more proactive. }\end{array}$ & 5.09 & 1.23 & 1.39 & 9.39 \\
\hline
\end{tabular}

The statistics of the PCI sub-indices are calculated for the period 2006-2018 
Table 7 Correlation matrix

\begin{tabular}{|c|c|c|c|c|c|c|c|c|}
\hline & (1) & (2) & (3) & (4) & (5) & $(6)$ & (7) & (8) \\
\hline Revenues (1) & 1.000 & & & & & & & \\
\hline Profits (2) & 0.112 & 1.000 & & & & & & \\
\hline State ownership (3) & 0.071 & 0.123 & 1.000 & & & & & \\
\hline State governance (4) & 0.095 & 0.059 & 0.695 & 1.000 & & & & \\
\hline Owner age (5) & 0.070 & 0.073 & 0.190 & 0.099 & 1.000 & & & \\
\hline Firm age (6) & 0.084 & 0.102 & 0.174 & 0.112 & 0.442 & 1.000 & & \\
\hline Firm size (7) & 0.101 & 0.092 & 0.401 & 0.312 & 0.194 & 0.261 & 1.000 & \\
\hline Local governance quality (8) & -0.040 & -0.033 & -0.011 & -0.034 & -0.027 & 0.071 & -0.068 & \\
\hline
\end{tabular}

All coefficients are significant at $1 \%$ level

\section{Appendix 4 PCI index methodology}

Brief methodology: The PCI is constructed in a threestep sequence, referred to as "the $3 \mathrm{Cs"}$

1. Collect business survey data and published data sources

2. Calculate ten sub-indices and standardize to a 10-point scale

3. Calibrate the composite PCI as the weighted mean of ten sub-indices with a maximum score of 100 points

Firms are selected using random sampling to mirror provincial populations. Stratification is used to make sure that firm age, legal type, and sector are accurately represented.

Items measured in the PCI sub-indices:

1. Entry costs

The goal of this sub-index is to assess the differences in entry costs for new firms across provinces. A measure of the following: length of business registration in days; length of business re-registration in days; percentage of firms that need additional licenses/permits; number of licenses and permits necessary to start operations after 2010; number of days to wait for land use right certificate; percentage of firms waiting more than a month to complete all steps necessary to start operations; percentage of firms waiting more than 3 months to complete all steps necessary to start operations; percentage of firms registering or re-registering through one-stop-shop; proce- 
dures at one-stop shop are transparently listed (\% agree); guidance and instruction on procedures at one-stop shop are clear and adequate (\% agree); staffs at one-stop shop are professional and knowledgeable (\% agree); staffs at one-stop shop are friendly ( $\%$ agree); IT application at one-stop shop is good (\% agree); none of the statements above is true (\% agree)

2. Land access and security of tenure

A measure combining two dimensions of the land problems confronting entrepreneurs: how easy it is to access land and the security of tenure once land is acquired, including the following: percentage of firms that own land and are in possession of a land use right certificate (LURC); percentage of land that has been registered and provided with official LURCs; percentage of firms that say non-state enterprises do not have difficulties in accessing land or expanding premises; firms' rating of expropriation risk (1, very high, to 5, very low); percentage of firms that say compensation for land is always or highly likely fair; percentage of firms that agree that changes in government land prices reflect changes in market prices; percentage of firms that have completed land procedures in the last two years and have encountered no difficulties in land-related procedures; percentage of firms that want to have LURCs but do not have LURCs because of complicated procedures and troublesome staffs.

3. Transparency and access to information

A measure of whether firms have access to the proper planning and legal documents necessary to run their businesses, whether those documents are equitably available, whether new policies and laws are communicated to firms and predictably implemented, and the business utility of the provincial webpage: access to planning documents ( 1 = easy to access; $5=$ impossible to access); access to legal documents $(1=$ easy to access; 5 = impossible to access); relationship important or very important to get access to provincial documents (\% important or very important); negotiations with tax authority are an essential part of doing business (\% agree or strongly agree); predictability of implementation of central laws at the provincial level (\% usually or always); firm gives comments on government regulation (\%); openness and quality of provincial webpage; business associations' role in advising and countering provincial polices (\% important or very important); percentage of firms have accessed provincial websites (\%); budget documents have enough details for use in business activities (\% yes); budget documents are published right after being approved (\% yes).

4. Time costs and regulatory compliance

A measure of how much time firms waste on bureaucratic compliance, as well as how often and for how long firms must shut their operations down for inspections by local regulatory agencies: percentage of firms spending over $10 \%$ of their time on understanding and complying with regulations; median number of inspections (all agencies); median tax inspection hours; government officials are effective (\% strongly agree or agree); government officials are friendly (\% strongly agree or agree); firms do not have to travel many trips to obtain stamps and signatures (\% strongly agree or agree); paperwork is simple (\% strongly agree or agree); fees are listed publicly (\% strongly agree or agree); no noticeable improvements are made (\% strongly agree or agree).

5. Informal charges

A measure of how much firms pay in informal charges, how much of an obstacle those extra fees pose for their business operations, whether payment of those extra fees results in expected results or "services", and whether provincial officials use compliance with local regulations to extract rents: enterprises in my line of business usually have to pay for informal charges (\% agree or totally agree); percentage of firms paying over $10 \%$ of their revenue for informal charges; rent-seeking phenomenon is popular in handling administrative procedures for businesses (\% strongly agree or agree); percentage of firms saying that informal charges usually or always deliver expected results; informal charges are at acceptable levels (\% strongly agree or agree).

6. Proactivity of provincial leadership

A measure of the creativity and cleverness of provinces in implementing central policy, designing their own initiatives for private sector development, and working within sometimes unclear national regulatory frameworks to assist and interpret in favour of local private firms: firms' assessment of the attitude of provincial government toward private sector (\% positive or fairly 
positive); the PPC is flexible within the legal framework to create favourable business environment for non-state firms (\% strongly agree or agree); the PPC is very proactive and innovative in solving new problems (\% strongly agree or agree); there are good initiatives at the provincial level but they are not well implemented by departments (\% strongly agree or agree); provincial leaders have good policies that are well implemented at district level (\% strongly agree or agree); province's reaction to lack of clarity in central policies/documents: \% "delay and seek instructions" and "do nothing".

7. Business support services

Used to be named "Private Sector development services", this is a measure of provincial services for private sector trade promotion, provision of regulatory information to firms, business partner matchmaking, provision of industrial zones or industrial clusters, and technological services for firms: number of trade fairs held by province in previous year and registered for present year; ratio of the total number of service providers to the total number of firms (\%); ratio of the number of non-state and FDI service providers to the total number of service providers (\%); firm has used business information search services (\%); firm used private provider for above business information search services (\%); firm intends to use above service provider again for business information search services (\%); firm has used consulting on regulatory information (\%); firm used private provider for consulting on regulatory information (\%); firm intends to use above service provider again for consulting on regulatory information (\%); firm has used business match making services (\%); firm used private provider for business match making services (\%); firm intends to use above service provider again for business match making services (\%); firm has used trade promotion services (\%); firm used private provider for trade promotion services (\%); firm intends to use above service provider again for trade promotion services (\%); firm has used technology related services (\%); firm used private provider for technology related services (\%); firm intends to use above service provider again for technology related services (\%); firm has used accounting and financing training services (\%); firm used private provider for above accounting and financing training services (\%); firm intends to use above service provider again for accounting and financing training services (\%); firm has used business administration training services (\%); firm used private provider for business administration training services (\%); firm intends to use above service provider again for business administration training services (\%).

8. Labour and training

A measure of the efforts by provincial authorities to promote vocational training and skills development for local industries and to assist in the placement of local labour: services provided by provincial agencies: general education (\% very good or good); services provided by provincial agencies: vocational training (\% very good or good); firm has used labour exchange services (\%); firm used private provider for above labour exchange services (\%); firm intends to use above service provider again for labour exchange services (\%); percentage of total business costs spent on labour training; percentage of total business costs spent on labour recruitment; overall satisfaction with labour (\% agreeing labour meets firm needs); ratio of vocational training school graduates to untrained labourers; secondary school graduates as \% of workforce; percentage of workers having completed training at vocational schools.

9. Legal institutions

A measure of the private sector's confidence in provincial legal institutions, whether firms regard provincial legal institutions as an effective vehicle for dispute resolution, or as an avenue for lodging appeals against corrupt official behaviour: legal system provided mechanism for firms to appeal against officials' corrupt behaviour (\% always or usually); firm confident that legal system will uphold property rights and contracts (\% strongly agree or agree); cases filed by non-state entities at Provincial Economic Court per 100 firms; business used courts or other legal institutions to resolve disputes (\%); nonstate claimants as a percentage of claimants at Provincial Economic Court; median months to resolve court cases; median formal and informal costs as a percentage of case; provincial court judge economic cases by the law (\% agree or strongly agree); provincial court resolve economic cases quickly (\% agree or strongly agree); court judgements are enforced quickly (\% agree or strongly agree); legal aid agencies support business to use laws to sue when dis- 
putes arise (\% agree); formal and informal costs are acceptable (\% agree or strongly agree); judgement by the court is fair (\% agree or strongly agree); willingness to use court in case a dispute arises (\% yes).

More information about the methodology is available at https://pcivietnam.vn/en/about/pci-methodology.html.

Open Access This article is licensed under a Creative Commons Attribution 4.0 International License, which permits use, sharing, adaptation, distribution and reproduction in any medium or format, as long as you give appropriate credit to the original author(s) and the source, provide a link to the Creative Commons licence, and indicate if changes were made. The images or other third party material in this article are included in the article's Creative Commons licence, unless indicated otherwise in a credit line to the material. If material is not included in the article's Creative Commons licence and your intended use is not permitted by statutory regulation or exceeds the permitted use, you will need to obtain permission directly from the copyright holder. To view a copy of this licence, visit http://creativecommons.org/licenses/by/4.0/.

\section{References}

Agostino, M., \& Trivieri, F. (2014). Does trade credit play a signalling role? Some evidence from SMEs microdata. Small Business Economics, 42(1), 131-151. https://doi. org/10.1007/s11187-013-9478-8

Aidis, R., Estrin, S., \& Mickiewicz, T. (2008). Institutions and entrepreneurship development in Russia: A comparative perspective. Journal of Business Venturing, 23(6), 656672. https://doi.org/10.1016/j.jbusvent.2008.01.005

Allen, F., Qian, J., \& Qian, M. (2005). Law, finance, and economic growth in China. Journal of Financial Economics, 77(1), 57-116. https://doi.org/10.1016/j.jfineco.2004.06.010

Anwar, S., \& Nguyen, L. P. (2014). Is foreign direct investment productive? A case study of the regions of Vietnam. Journal of Business Research, 67(7), 1376-1387. https://doi. org/10.1016/j.jbusres.2013.08.015

Awaworyi Churchill, S., Munyanyi, M. E., Smyth, R., \& Trinh, T.-A. (2020). Early life shocks and entrepreneurship: Evidence from the Vietnam War. Journal of Business Research. https://doi.org/10.1016/j.jbusres.2020.11.009

Bian, Y. (2017). The Comparative Significance of Guanxi. Management \& Organization Review, 13(2), 261-267. https://doi.org/10.1017/mor.2017.20

Bian, Y. (2018). The Prevalence and the Increasing Significance of Guanxi. China Quarterly, 2018(235), 597-621. https://doi.org/10.1017/S0305741018000541

Boudreaux, C. J., \& Nikolaev, B. (2019). Capital Is Not Enough: Opportunity Entrepreneurship and Formal Institutions. Small Business Economics, 53(3), 709-738. https://doi.org/10.1007/s11187-018-0068-7

Burt, R. S., \& Burzynska, K. (2017). Chinese Entrepreneurs, Social Networks, and Guanxi. Management and
Organization Review, 13(2), 221-260. http://journals. cambridge.org/action/displayBackIssues?jid=MOR.

Chase, K. S., \& Murtha, B. (2019). Selling to Barricaded Buyers. Journal of Marketing, 83(6), 2-20. https://doi.org/10. 1177/0022242919874778

Chen, W. (2015). Does the colour of the cat matter? The red hat strategy in China's private enterprises. Management and Organization Review, 3(1), 55-80. https://doi.org/10. 1111/j.1740-8784.2007.00059.x

Cheng, L. T. W., Chan, R. Y. K., \& Leung, T. Y. (2018). Impact of perk expenditures and marketing expenditures on corporate performance in China: The moderating role of political connections. Journal of Business Research, 86(May), 83-95. https://doi.org/10.1016/j.jbusres.2018.01.046

De Jong, G., Tu, P. A., \& Van Ees, H. (2012). Which entrepreneurs bribe and what do they get from it? Exploratory evidence from Vietnam. Entrepreneurship: Theory and Practice, 36(2), 323-345. https://doi.org/10.1111/j.15406520.2010.00400.x

Diewert, W. E., \& Nakamura, A. O. (2007). The measurement of productivity for nations. In J. J. Heckman \& E. E. Leamer (Eds.), Handbook of econometrics, 6 Part A (pp. 4501-4586). Amsterdam: Elsevier. https://doi.org/10. 1016/S1573-4412(07)06066-7

Ding, R., Li, J., \& Wu, Z. (2018). Government affiliation, real earnings management, and firm performance The case of privately held firms. Journal of Business Research, 83(Feb), 138-150. https://doi.org/10.1016/j.jbusres.2017.10.011

Ding, S., Guariglia, A., \& Harris, R. (2016). The determinants of productivity in Chinese large and medium-sized industrial firms, 1998-2007. Journal of Productivity Analysis, 45(2), 131-155. https://doi.org/10.1007/s11123-015-0460-0

Ding, S., Jia, C., Qu, B., \& Wu, Z. (2015). Corporate risk-taking: Exploring the effects of government affiliation and executives' incentives. Journal of Business Research, 68(6), 1196-1204. https://doi.org/10.1016/j.jbusres.2014.11.014

Divya Verma, G., \& Abhijit, P. (2018). From welfare to wealth creation: A review of the literature on privatization of state-owned enterprises. International Journal of Public Sector Management, 31(2), 265-286. https://doi.org/10. 1108/IJPSM-03-2017-0096

Do, H., Patel, C., Budhwar, P., Katou, A. A., Arora, B., \& Dao, M. (2020). Institutionalism and its effect on HRM in the ASEAN context: challenges and opportunities for future research. Human Resource Management Review, 30(4), 100729. https://doi.org/10.1016/j.hrmr.2019.100729

Du, J., \& Girma, S. (2012). Firm size, source of finance, and growth-Evidence from China. International Journal of the Economics of Business, 19(3), 397-419. http://www. tandfonline.com/loi/cijb20.

Du, J., Guariglia, A., \& Newman, A. (2015). Do social capital building strategies influence the financing behavior of Chinese private small and medium-sized enterprises? Entrepreneurship Theory \& Practice, 39(3), 601-631. https://doi.org/10.1111/etap.12051

Du, J., Liu, X., \& Zhou, Y. (2014). State advances and private retreats? - Evidence of aggregate productivity decomposition in China. China Economic Review, 31(Dec), 459-474. https://doi.org/10.1016/j.chieco.2014.03.002

Du, J., \& Mickiewicz, T. (2016). Subsidies, rent seeking and performance: Being young, small or private in China. 
Journal of Business Venturing, 31(1), 22-38. https://doi. org/10.1016/j.jbusvent.2015.09.001

Faccio, M. (2010). Differences between politically connected and nonconnected firms: A cross-country analysis. Financial Management, 39(3), 905-928. https://doi.org/10. 1111/j.1755-053X.2010.01099.X

Feng, X., Johansson, A. C., \& Zhang, T. (2015). Mixing business with politics: Political participation by entrepreneurs in China. Journal of Banking \& Finance, 59(Oct), 220235. https://doi.org/10.1016/j.jbankfin.2015.06.009

Fisman, D., Fisman, R. J., Galef, J., Khurana, R., \& Wang, Y. (2012). Estimating the value of connections to Vice-President Cheney. The B.E. Journal of Economic Analysis \& Policy, 13(3) https://doi.org/10.1515/1935-1682.3272

Gan, J., Guo, Y., \& Xu, C. (2017). Decentralized privatization and change of control rights in China. The Review of Financial Studies, 31(10), 3854-3894. https://doi.org/10. 1093/rfs/hhx100

Goldman, E., Rocholl, J., \& So, J. (2009). Do politically connected boards affect firm value? The Review of Financial Studies, 22(6), 2331-2360. https://doi.org/10.1093/rfs/hhn088

Guariglia, A., \& Liu, P. (2014). To what extent do financing constraints affect Chinese firms' innovation activities? International Review of Financial Analysis, 36(12), 223240. http://www.sciencedirect.com/science/journal/10575 219.

Guo, C., \& Miller, J. K. (2010). Guanxi dynamics and entrepreneurial firm creation and development in China. Management \& Organization Review, 6(2), 267-291. https:// doi.org/10.1111/j.1740-8784.2010.00180.x

Johnson, S., \& Mitton, T. (2003). Cronyism and capital controls: evidence from Malaysia. Journal of Financial Economics, 67(2), 351-382. https://doi.org/10.1016/S0304405X(02)00255-6

K De, P., \& Nagaraj, P. (2014). Productivity and firm size in India. Small Business Economics, 42(4), 891-907. https:// doi.org/10.1007/s11187-013-9504-X

Khuong, V. M. (2015). Can Vietnam achieve more robust economic growth? Insights from a comparative analysis of economic reforms in Vietnam and China. Journal of Southeast Asian Economies, 32(1), 52-83. http://www.iseas.edu.sg/ flagship-publications/journal-of-southeast-asian-economies.

Kuratko, D., Fisher, G., Bloodgood, J., \& Hornsby, J. (2017). The paradox of new venture legitimation within an entrepreneurial ecosystem. Small Business Economics, 49(1), 119-140. https://doi.org/10.1007/s11187-017-9870-x

Lan Phi, N., \& Anwar, S. (2011). Fiscal decentralisation and economic growth in Vietnam. Journal of the Asia Pacific Economy, 16(1), 3-14. https://doi.org/10.1080/13547860. 2011.539397

Li, H., Meng, L., Wang, Q., \& Zhou, L.-A. (2008). Political connections, financing and firm performance: Evidence from Chinese private firms. Journal of Development Economics, 87(2), 283-299. https://doi.org/10.1016/j.jdeveco.2007.03.001

Li, L., Chen, J., Gao, H., \& Xie, L. (2019). The certification effect of government R\&D subsidies on innovative entrepreneurial firms' access to bank finance: Evidence from China. Small Business Economics, 52(1), 241-259. https://doi.org/10.1007/s11187-018-0024-6

Lipton, D., Sachs, J., \& Summers, L. H. (1990). Privatization in Eastern Europe: The case of Poland. Brookings Papers on Economic Activity, 1990(2), 293-341. https://doi.org/ $10.2307 / 2534508$

Liu, Y., Zhang, Y., Fang, H., \& Chen, X. (2021). SMEs' line of credit under the COVID-19: Evidence from China. Small Business Economics: An Entrepreneurship Journal, lhttps://doi.org/10.1007/s11187-021-00474-9

Luo, X. R., Yang, L., \& He, X. (2019). Can one stone kill two birds? Political relationship building and partner acquisition in new ventures. Entrepreneurship Theory and Practice, 44(4), 817-841. https://doi.org/10.1177/1042258719855965

Luo, Y., Huang, Y., \& Wang, S. L. (2012). Guanxi and organizational performance: A meta-Analysis. Management \& Organization Review, 8(1), 139-172. https://doi.org/10. 1111/j.1740-8784.2011.00273.x

Luo, Y., \& Junkunc, M. (2008). How private enterprises respond to government bureaucracy in emerging economies: the effects of entrepreneurial type and governance. Strategic Entrepreneurship Journal, 2(2), 133-153. https://doi.org/10.1002/sej.46

Makino, S., \& Tsang, E. W. K. (2011). Historical ties and foreign direct investment: An exploratory study. Journal of International Business Studies, 42(4), 545-557. http:// www.palgrave-journals.com/jibs/archive/index.html.

Malesky, E., McCulloch, N., \& Nhat, N. D. (2015). The impact of governance and transparency on firm investment in Vietnam. Economics of Transition, 23(4), 677-715. https://doi.org/10.1111/ecot.12068

Megginson, W. L., \& Netter, J. M. (2001). From state to market: A survey of empirical studies on privatization. Journal of Economic Literature, 39(2), 321-389. https://doi. org/10.1257/jel.39.2.321

Mirza, H., \& Giroud, A. (2004). Regionalization, foreign direct investment and poverty reduction: Lessons from Vietnam in ASEAN. Journal of the Asia Pacific Economy, 9(2), 223-248. http://www.tandfonline.com/loi/rjap20.

Nguyen, B. (2018). Is a bit more experience bad? The role of entrepreneurial experience on investment rate. International Journal of Entrepreneurial Behavior \& Research, 25(6), 1166-1187. https://doi.org/10.1108/IJEBR-06-2018-0375

Nguyen, B. (2019). Entrepreneurial reinvestment: Local governance, ownership, and financing matter - Evidence from Vietnam. Journal of Small Business Management, 57(2), 323-349. https://doi.org/10.1111/jsbm.12475

Nguyen, B., \& Canh, N. P. (2020). The effects of regional governance, education, and in-migration on business performance. Kyklos, 73(2), 291-319. https://doi.org/10.1111/kykl.12223

Nguyen, B., Mickiewicz, T., \& Du, J. (2018). Local governance and business performance in Vietnam: the transaction costs perspective. Regional Studies, 52(4), 542-557. https://doi.org/10.1080/00343404.2017.1341625

Nguyen, T. T., \& van Dijk, M. A. (2012). Corruption, growth, and governance: Private vs. state-owned firms in Vietnam. Journal of Banking and Finance, 36(11), 2935-2948. http://www.sciencedirect.com/science/journal/03784266.

Nguyen, T. V., Le, N. T. B., \& Freeman, N. J. (2006). Trust and uncertainty: A study of bank lending to private SMEs in Vietnam. Asia Pacific Business Review, 12(4), 547-568. https://doi.org/10.1080/13602380600571260

O'Toole, C. M., Morgenroth, E. L. W., \& Ha, T. T. (2016). Investment efficiency, state-owned enterprises and privatisation: Evidence from Viet Nam in Transition. Journal 
of Corporate Finance, 37(4), 93-108. https://doi.org/10. 1016/j.jcorpfin.2015.12.011

Peng, M. W., Lu, Y., Shenkar, O., \& Wang, D. Y. L. (2001). Treasures in the China house: A review of management and organizational research on Greater China. Journal of Business Research, 52(2), 95-110. https://doi.org/10. 1016/S0148-2963(99)00063-6

Pfeffer, J., \& Salancik, G. R. (1978). The external control of organizations: A resource dependence perspective (2009 ed.). Stanford Univ. Press https://doi.org/10.4324/9781315702001

Pham, T., \& Talavera, O. (2018). Discrimination, social capital, and financial constraints: The case of Viet Nam. World Development, 102(2), 228-242. https://doi.org/10.1016/j. worlddev.2017.10.005

Rand, J., \& Tarp, F. (2012). Firm-level corruption in Vietnam. Economic Development and Cultural Change, 60(3), 571595. http://www.journals.uchicago.edu/toc/edcc/current.

Reynolds, P. D. (2011). Informal and Early Formal Financial Support in the Business Creation Process: Exploration with PSED II Data Set. Journal of Small Business Management, 49(1), 27-54. https://doi.org/10.1111/j.1540-627X.2010.00313.x

Schmitz, H., Tuan, D. A., Hang, P. T. T., \& McCulloch, N. (2015). Drivers of economic reform in Vietnam's provinces. Development Policy Review, 33(2), 175-193. http:// onlinelibrary.wiley.com/journal/10.1111/\%28ISSN\% 291467-7679/issues.

Sharma, P., Cheng, L. T. W., \& Leung, T. Y. (2020). Impact of political connections on Chinese export firms' performance -- Lessons for other emerging markets. Journal of Business Research, 106(1), 24-34. https://doi.org/10. 1016/j.jbusres.2019.08.037

Song, Z., Nahm, A., \& Yang, J. (2016). Institutional environment, political connections of partial state ownership, and performance: An empirical study on listed private sector firms in China. International Journal of Social Economics, 43(8), 856-870. https://doi.org/10.1108/IJSE-10-2014-0210

Song, Z., Nahm, A., \& Zhang, Z. (2015). The value of partial state ownership in publicly listed private sector enterprises: Evidence from China. Post-Communist Economies, 27(3), 336-353. http://www.tandfonline.com/loi/cpce20.

Song, Z., Nahm, A., \& Zhang, Z. (2017). Partial state ownership, political connection, and financing: Evidence from Chinese publicly listed private sector enterprises. Emerging Markets Finance and Trade, 53(3), 611-628. https:// doi.org/10.1080/1540496X.2015.1097920

Suchman, M. C. (1995). Managing legitimacy: Strategic and institutional approaches. Academy of Management Review, 20(3), 571-610. https://doi.org/10.5465/amr. 1995.9508080331

Tran, H. T. (2019). Institutional quality and market selection in the transition to market economy. Journal of Business Venturing, 34(5), 1-27. https://doi.org/10.1016/j.jbusvent.2018.07.001

Tricker, R. I. (2015). Corporate governance : principles, policies, and practices (Third edition. ed.): Oxford University Press. https://search.ebscohost.com/login.aspx?direct= true $\& \mathrm{db}=$ cat00594a $\& \mathrm{AN}=$ aston. $\mathrm{b} 1669622 \&$ site $=$ edslive \&authtype $=$ ip, shib\&custid $=$ s 9815128

Valliere, D., \& Peterson, R. (2009). Entrepreneurship and economic growth: Evidence from emerging and developed countries. Entrepreneurship and Regional Development,
21(5-6), 459-480. http://www.tandfonline.com/loi/ tepn 20.

Van Thang, N., \& Freeman, N. J. (2009). State-owned enterprises in Vietnam: Are they "crowding out" the private sector? Post-Communist Economies, 21(2), 227-247. http://www.tandfonline.com/loi/cpce20.

Walder, A. G., \& Nguyen, G. H. (2008). Ownership, organization, and income inequality: Market transition in rural Vietnam. American Sociological Review, 73(2), 251-269. https://doi.org/10.1177/000312240807300204

Wang, F., Zhang, J., Xu, L., \& Shu, W. (2018). Political connections, internal control and firm value: Evidence from China's anti-corruption campaign. Journal of Business Research, 86(May), 53-67. https://doi.org/10.1016/j.jbusr es.2018.01.045

Wang, Q. (2015). Fixed-effect panel threshold model using Stata. Stata Journal, 15(1), 121-134. https://doi.org/10. 1177/1536867X1501500108

Wehrheim, D., Dalay, H. D., Fosfuri, A., \& Helmers, C. (2020). How mixed ownership affects decision making in turbulent times: Evidence from the digital revolution in telecommunications. Journal of Corporate Finance, 64(Oct), 1-21. https://doi.org/10.1016/j.jcorpfin.2020.101626

Welter, F. (2011). Contextualizing entrepreneurship-conceptual challenges and ways forward. Entrepreneurship theory and Practice, 35(1), 165-184. https://doi.org/10. 1111/j.1540-6520.2010.00427.x

Welter, F., \& Baker, T. (2020). Moving contexts onto new roads: Clues from other disciplines. Entrepreneurship Theory and Practice, 45(5) 1154-1175. https://doi.org/10. $1177 / 1042258720930996$

Williamson, O. E. (2000). The new institutional economics: taking stock, looking ahead. Journal of Economic Literature, 38(3), 595-613. http://www.aeaweb.org/jel/index.php.

Wong, W.-Y., \& Hooy, C.-W. (2018). Do types of political connection affect firm performance differently? Pacific-Basin Finance Journal, 51(Oct), 297-317. https://doi.org/10. 1016/j.pacfin.2018.08.009

Zhang, X., Yu, M., \& Chen, G. (2020). Does mixed-ownership reform improve SOEs' innovation? Evidence from state ownership. China Economic Review, 61(June), 1-22. https://doi.org/10.1016/j.chieco.2020.101450

Zhou, W. (2013). Political connections and entrepreneurial investment: Evidence from China's transition economy. Journal of Business Venturing, 28(2), 299-315. https:// doi.org/10.1016/j.jbusvent.2012.05.004

Zhou, W. (2014). Regional institutional development, political connections, and entrepreneurial performance in China's transition economy. Small Business Economics, 43(1), 161-181. https://doi.org/10.1007/s11187-013-9527-3

Zhou, W. (2017). Institutional environment, public-private hybrid forms, and entrepreneurial reinvestment in a transition economy. Journal of Business Venturing, 32(2), 197214. https://doi.org/10.1016/j.jbusvent.2016.11.002

Publisher's Note Springer Nature remains neutral with regard to jurisdictional claims in published maps and institutional affiliations. 